\title{
ARTICLE TYPE \\ CATALYTIC PROCESSES FOR LIGNIN VALORIZATION INTO FUELS AND CHEMICALS (AROMATICS)
}

\author{
M. Ventura ${ }^{\mathrm{a}}$, M. E. Domine ${ }^{* a}$, M. Chávez-Sifontes ${ }^{\mathrm{b}}$
}

anstituto de Tecnología Química, ITQ (UPV-CSIC). Universitat Politècnica de València. Consejo Superior de Investigaciones Científicas. Avda Los Naranjos S/N, 46022, Valencia, Spain; ${ }^{b}$ Escuela de Química, Facultad de Ciencias Naturales y Matemática, Universidad de El Salvador, Final Av. de Mártires y Héroes del 30 julio, San Salvador, El Salvador

A R T I C L E H I S T O R Y

Received:

Revised:

Accepted:

DOI:

\begin{abstract}
Valorization of lignocellulosic biomass becomes a sustainable alternative against the constant depletion and environmental problems of fossil sources necessary for the production of chemicals and fuels. In this context, a wide range of renewable raw materials can be obtained from lignocellulosic biomass in both polymeric (i.e. cellulose, starch, lignin) and monomeric (i.e. sugars, polyols, phenols) forms. Lignin and its derivatives are interesting platform chemicals for industry, although mainly due to its refractory characteristics its use has been less considered compared to other biomass fractions. To take advantage of the potentialities of lignin, it is necessary to isolate it from the cellulose/hemicellulosic fraction, and then apply depolymerization processes; the overcoming of technical limitations being a current issue of growing interest for many research groups. In this review, significant data related to the structural characteristics of different types of commercial lignins are presented, also including extraction and isolation processes from biomass, and industrial feedstocks obtained as residues from paper industry under different treatments. The review mainly focuses on the different depolymerization processes (hydrolysis, hydrogenolysis, hydrodeoxygenation, pyrolysis) up to now developed and investigated analyzing the different hydrocarbons and aromatic derivatives obtained in each case, as well as the interesting reactions some of them may undergo. Special emphasis is done on the development of new catalysts and catalytic processes for the efficient production of fuels and chemicals from lignin. The possibilities of applications for lignin and its derivatives in new industrial processes and their integration into the biorefinery of the future are also assessed.
\end{abstract}

Keywords: lignin valorization; lignin depolymerization; biomass derivatives; catalytic processes; aromatics compounds; platform chemicals.

\section{INTRODUCTION}

The growing demand for fuels and chemicals together with the dependence on non-renewable petroleum should be addressed simultaneously through the development of sustainable technologies that would enable the efficient utilization of renewable resources[1-2]. Carbon-neutral and nonedible starting material represents an attractive source of chemicals or fuels, such as lignocellulosic biomass, produced in huge quantities from forestry and agricultural activity worldwide[3].

*Address correspondence to this author: Instituto de Tecnología Química, ITQ (UPV-CSIC). Universidad Politécnica de Valencia. Consejo Superior de Investigaciones Científicas. Avda Los Naranjos S/N, 46022, Valencia, Spain; Tel/Fax: +34-963879696, +34-963877809; E-mail: mdomine@itq.upv.es
Moreover, food waste has been put forward as an economically significant, lignocellulose-rich resource. In the past decade, significant advances have been achieved regarding the development of biorefineries suitable for the fractionation of lignocellulose to its main constituents: cellulose, hemicellulose, and lignin[4].

Lignin is one of the most abundant biopolymers in plants that forms their cell wall along with cellulose and hemicellulose. These biopolymers are arranged in a nanostructural regulated organization, which results as lignincarbohydrates nets. The distribution of these three biopolymers in the network changes depending on the type of plant. In the case of wood, for example, the composition generally reports values in the following ranges: Cellulose: 40-50\%, Hemicellulose: 25-35\% and Lignin: 15-20\%[5-6]. 
Lignin can be classified by the biomass type from which they are extracted, such as: softwood lignins or hardwood lignins. This classification can be extended to its extraction method, such as steam explosion lignin, Kraft lignin, Organosolv lignin, alkaline oxidation lignin, pyrolysis lignin, etc[5].

In order to improve the economic facts on biorefineries, and to overcome the high energy costs usually associated, all these three major constituents should be properly valorized. Extensive efforts have been performed for the conversion of these three biopolymers, in this way novel chemo- and bioroutes have been developed in the latest years[7], where a wide range of chemical (thermo-chemical, catalytic, etc.) and biological processes have been applied for the transformation of cellulose (and cellulose-rich feedstocks) and hemicellulose into valuable chemical products[8-9]. Lignin is one of the largest renewable source of aromatic building blocks in nature with a significant potential to be used as starting material for the production of bulk or functionalized aromatic compounds to replace those analogs petroleum derived universally used, such as benzene, toluene or xylene[10]. Nevertheless, lignin transformation has attracted less attention at the beginning of biorefineries development, mainly due to its recalcitrant characteristics and the consequent difficulties found during its processing (i.e. coke formation, re-polymerization, etc.). Thus, to exploit the lignin potential is necessary to develop more efficient methods to isolate it from the cellulosic/hemicellulosic matrix, and then to apply depolymerization processes, by facing several technical limitations surpassing current topics of growing interest for many research groups. The annual production of lignin coming from different sources, such as wood or paper industry is estimated in the range of 5-36 x $10^{8}$ tons. Lignin Market size is set to surpass USD 960 million by 2024; according to a new research report by Global Market Insights, Inc. (Figure 1)[11].

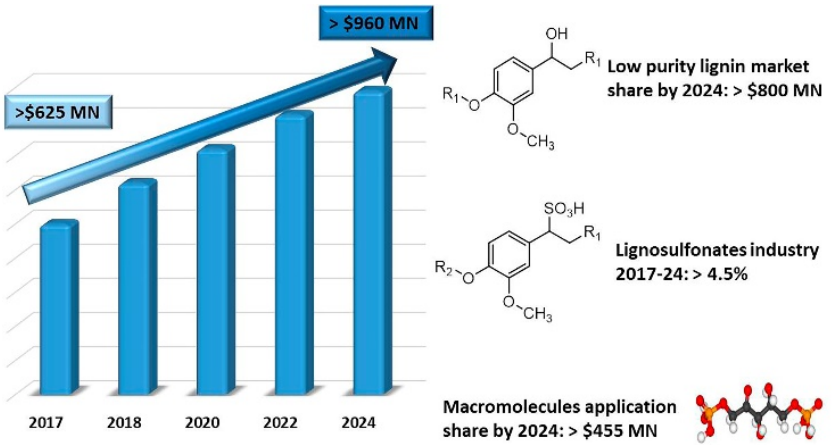

Figure 1. Lignin market. Adapted from Global Market insights, 2018[11].

The grown of environmental concerns owing to air pollution along with technological advancements in bioenergy and biofuel will drive lignin market size. Increased usage of material admixtures in concrete owing to properties such as water reduction has promoted product demand in the construction sector. Widespread application outlook in binders and adhesives have further catalyzed product demand. However, and as it was mentioned-before, the conversion of lignin was found extremely challenging, mainly due to the robustness and the complexity of its structure[12]. In this review, an overview on the type of lignin available and ready for usage will be given firstly. Then, different types of depolymerization processes developed for the efficient lignin conversion will be described, with special emphasis on the recent advances in thermo-chemical and mainly catalytic processes for lignin transformation into valuable products. In addition, this review will explain how lignin and its derivatives become a suitable source of aromatics chemicals for industry.

\section{GENERAL CONSIDERATIONS.}

Lignin depolymerization is an exciting task ruled by the structural complexity and recalcitrance of this aromatic biopolymer, which is randomly organized together by strong $\mathrm{C}-\mathrm{C}$ and $\mathrm{C}-\mathrm{O}$ bonds[12]. The structural definition of lignin has never been clear, unlike other natural polymers such as cellulose or proteins, due to the complexity that affects to their isolation, composition analysis, and structural characterization[13]. The problem of a precise lignin definition is associated with the nature of multiple structural units, not repeated regularly, since the composition and structure of lignin vary depending on its origin and the extraction or isolation method used. Figure 2 shows a representative lignin structure with its most common linkages.

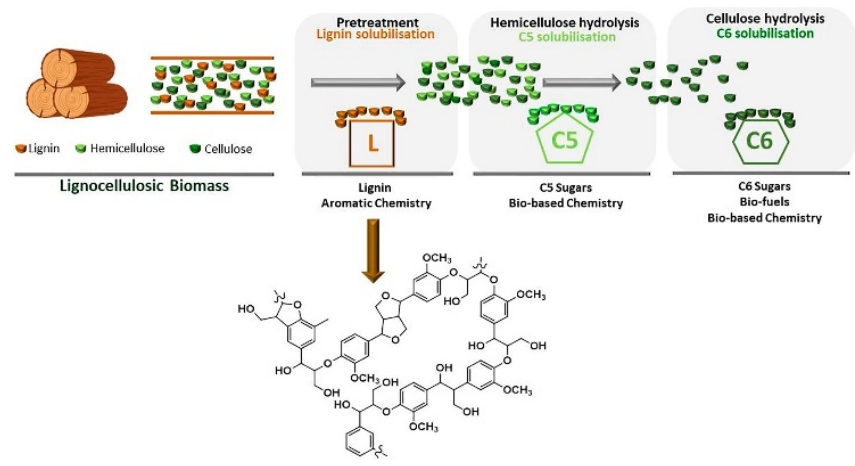

Figure 2. Schematic representation of lignin isolation process and its structure.

Generally, lignin can be defined as a copolymer built by three basic phenylpropanol-monomeric units (monolignols): $p$-coumaryl alcohol, coniferyl alcohol and sinapyl alcohol, whose structures are shown in Figure 3[14-15]. Many different linkages are found in lignin structure (see Figure $3 . b)$, the type and ratio depend on the type of plant from lignin was extracted. Among all, the recurring type is the $\beta$ O-4 linkage, therefore it has been the aim of the most depolymerization strategies. Depolymerization of lignin should be focused on the conversion into aromatic compounds with high yields and selectivity enough to allow separation and subsequent valorization to well-defined products. In addition, lignin is also considered as a racemic mixture, as it is evidenced by analysis of various dimeric fragments such as $( \pm)$-pinoresinoles and $( \pm)$ siringoresinoles[16].

The percentage distribution of main monolignols depends on plant type, as shown in Table 1[15,17]. The most abundant monolignol in softwoods is coniferyl alcohol, which can exceed $95 \%$ of monolignols present, while in 
hardwoods mainly coexist coniferyl and sinapyl alcohols. In case of herbaceous plants, may have similar proportions of the three main monolignols.
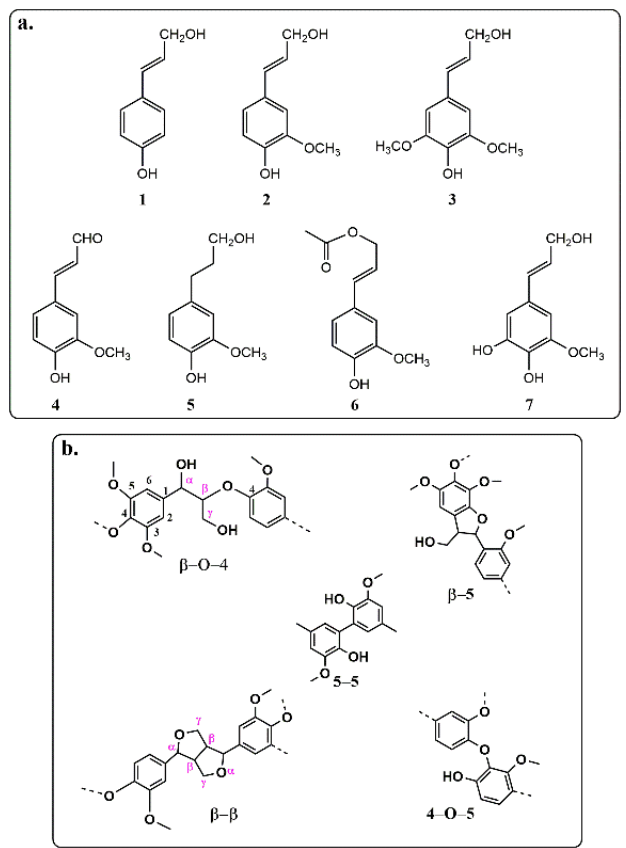

Figure 3. a. Most common type of monolignols as building blocks in lignin: 1: $p$-coumaryl alcohol, 2: coniferyl alcohol, 3: sinapyl alcohol; other monolignols (coniferylderivatives): 4: coniferaldehyde, 5: dihydroconiferyl alcohol, 6: coniferyl-9-acetate, 7: 5-hydroxyconiferyl; b. Common linkages in lignin.

Table 1. Percentage of lignin monolignols present in several type of plants.

\begin{tabular}{|c|l|c|c|c|}
\hline \multicolumn{2}{|c|}{ Plant type } & \multicolumn{3}{c|}{ Percentages } \\
\cline { 3 - 5 } Gymnosperms & $\begin{array}{l}\text { Coniferous } \\
\text { (softwoods) } \\
\text { alcohol }\end{array}$ & $\begin{array}{c}\text { Coniferyl } \\
\text { alcohol }\end{array}$ & $\begin{array}{c}\text { Sinapyl } \\
\text { alcohol }\end{array}$ \\
\hline \multirow{2}{*}{ Angyosperms } & $\begin{array}{l}\text { Eudicotyledonous } \\
\text { (hardwoods) }\end{array}$ & $0-8$ & $>95$ & 0 \\
\cline { 2 - 5 } & $\begin{array}{l}\text { Monocotyledonous } \\
\text { (grasses) }\end{array}$ & $5-35$ & $35-80$ & $20-55$ \\
\hline
\end{tabular}

\section{LIGNIN EXTRACTION AND ISOLATION METHODS}

Lignin can be isolated from lignocellulosic material by many different processes involving mechanical and/or chemical methods. These processes can be grouped in two main groups. The first group is classified depending on the solubility of lignin (Figure 4). Therefore, there exist methods in which the cellulose and hemicellulose are extracted by dissolution, leaving lignin as insoluble residue[18]; and methods which involve the dissolution of lignin, leaving insoluble residues as cellulose and hemicellulose, followed by the recovery of lignin from the liquid phase[19-20]. Second group of processes is classified by the extension of the structural modifications induced in lignin (Figure 4)[21]. Then, it is possible to find methods where a significant modification of lignin is produced, thus giving four types of lignin: sulfite[22], klason[23-24], alkali[25], and Kraft lignin[26-27]; and methods where mild structural modifications have been done giving lignin-type commonly named as Organosolv[28] milled wood[29], cellulolytic enzyme[30] and ionic liquid lignin[31-32], respectively.

The type of manufacturing process of pulp used for papermaking determines the type of lignin industrially available, or at least the most affordable today. Most of the processes are focused on obtaining high quality cellulose, therefore lignin attained by this method has low quality and present many drawbacks associated to its isolation. This review is focused on the major lignin used nowadays; therefore, three types of lignin obtained with significant modifications will be described. These correspond to the three major chemical processes for the manufacture of pulp: sulfite type, Kraft[33] and soda, which are described below[34-35]. In addition, numerous reports in patents and papers refer to the use of commercially available organosolv-type lignin as feedstock for depolymerization reactions. Then, the process for Orgnasolv lignin will be also described in this section.

\subsection{Sulfite lignin}

a. Overview: sulfite lignin is produced by the pulping process and is characterized by the incorporation of about $4-8 \%$ of sulfur in the form of sulfonate groups, providing water-soluble lignin[36]. It was originally developed based on the use of calcium bisulfite, an inexpensive chemical to manufacture the so-called "cellulose pasta". The lack of appropriate technology for recovery this chemical from the mixture generated, led to development of other uses for these mixtures, such as the production of calcium lignosulfonates. Technology used for sulfite pulp has evolved to include the use of other sulfites and bisulfites such as magnesium, ammonium and/or sodium. Thus, the lignosulfonates obtained have also found applications in some cases specially adapted for a specific cation type. Over time, sulfite pulp process began losing ground to its competitor: Kraft method, which is more versatile allowing a better product recovery (solid waste). In fact, sulphite pulp production has been reduced by nearly 20 million tons in 1980 to about 7 million tons at present. Current expectations point out to a continuing decline in the production of pulp by this process. Despite this trend, the production of lignin sulfite type has managed to remain relatively stable in response to global demand, where the recent decline in the consumption of Western Europe, North America and Japan was offset by increases in the demand for part of China, India and elsewhere.

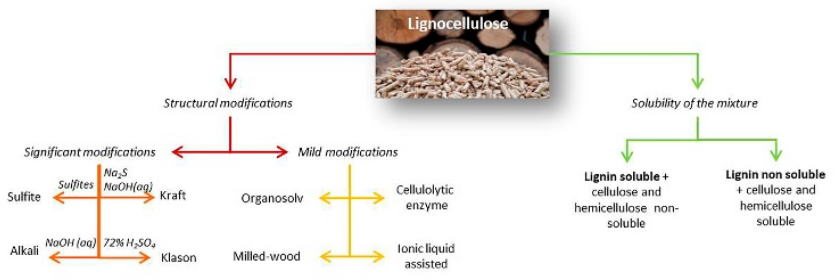

Figure 4. Methods for lignin extraction and/or isolation. 
b. Process: In the process of sulfite, pulping wood digestion at $140-170{ }^{\circ} \mathrm{C}$ with an aqueous solution of sodium sulfite or bisulfite, ammonium, magnesium or calcium is carried out. The $\mathrm{pH}$ of the solution depends on the type of the salt used. During the digestion process, various chemical processes take place, including breaking the bonds between lignin and carbohydrates, rupture of the intramolecular bonds of lignin (C-O), and sulfonation of the aliphatic moieties of lignin. Sulfur is added to the lignin molecules during the process $(4-8 \%)$, mostly in the form of sulfonate groups. This process is not selective to remove lignin resulting in mixtures also containing hemicellulose and carbohydrates. Therefore, further separation processes such as alcoholic fermentation of sugars and subsequent distillation, precipitation or chemical degradation of sugars are required to obtain lignin with high purity level. Because of the sulfonation process, catalytic depolymerization of lignin is negatively affected by the incorporation of sulfonate groups, and it continues being a challenging task[37-38].

c. Properties: The sulfur content reported in literature ranges between 4-8\% percent mostly in the form of sulfonate, although other sulfur species (i.e. sulfite and sulfate) also appear, thus providing water-soluble lignin. Usually sulfonation degree of industrial lignins ranges from 0.17 to 0.65 sulfonate groups per phenylpropane unit, or about 0.9 to 3.3 sulfonate groups per 1,000 grams of lignin (Borregaard Lignotech). The range of values reported for lignosulfonates molecular mass is large, from 1,000 to 150,000 amu. Experiments using spectroscopic correlations suggest lignosulfonates are nano-dimensional systems with two domains, having particle sizes of $10 \mathrm{~nm}$ (single macromolecule) and 100-200 nm (associated macromolecules). Studies by Differential Scanning Calorimetry have determined that lignosulfonates do not have glass transition temperature, showing two peaks (at $320{ }^{\circ} \mathrm{C}$ and $450{ }^{\circ} \mathrm{C}$ ) corresponding to decomposition temperatures of carbohydrates and lignin respectively.

\subsection{Kraft Lignin}

a. Overview: While the process for producing Kraft pulp is one of the most predominant in the market $(50-70 \%$ of worldwide production)[39], currently the recovery of Kraft lignin for chemical uses is not widely practiced. Plants of Kraft pulp have become to a highly integrated system of engineering for the recovery of the products present in the chemical pulp and energy based on the combustion of pulping liquor (black liquor). This recovery system is essential for economy and performance of the pulp plant using the Kraft process, which allows them concentrate their attention on paper business. Therefore, the recovered amount of Kraft lignin in relation to the amount of lignin sulphite recovered for chemical uses is rather small. This may change in the future due to constant efficiency improvements in modern plants, which can generate an excess of energy in relation to their needs[33].

b. Process: Kraft lignin is modified by a digestion process with a mixture of sodium hydroxide and sodium sulfide at around $170{ }^{\circ} \mathrm{C}$, breaking most $\alpha$-aryl ether and $\beta$-aryl ether bonds. These reactions generate fragments with phenolic groups that are soluble in the alkaline medium generated during digestion process. Furthermore, the system is attacked by strongly nucleophilic hydrogen sulfide ions, leading to a sulfur-enriched structure (1.5-3.0\% sulfur). During digestion process, several reactions occur such as itself re-condensation, leading in this way a very complex mixture. Various processes have been developed to recover lignin from the pulp wastewater[40]. Precipitation process is one of the earliest and most broadly used industrial process to recover Kraft lignin, but this process consumes high amounts of chemicals being as well non eco-friendly due to the handling of large amount of acid[41]. Besides, ultrafiltration and ion-exclusion are also widely used to separate Kraft lignin in cooking liquor by using ionexchange resins, but these techniques suffer fouling problem of the membranes and high operation cost[42]. Recently more effectives method have been developed by the use of an emulsion liquid membrane system getting 95\% of extracted lignin[43].

c. Properties: unmodified industrial Kraft lignins are characterized by a relatively high degree of purity. Analysis shows that acid-insoluble lignin fraction is about $90 \%$, acidsoluble fraction is only $3 \%$, and sugar content is less than $2.3 \%$ (corresponding to fractions of high molecular weight carbohydrates). The sulfur content of this type of lignin is 1.5-3.0\%, which corresponds to elemental sulfur and inorganic sulfur. The molecular weight of Kraft lignin is between 2,500 and 39,000 amu, also containing hydroxyl groups in the range of 1.2 to $1.27 \mathrm{OH}$ groups per $\mathrm{C} 9$ units of which $60 \%$ have phenolic nature. This type of lignin does not present aldehyde groups since they are very reactive under reaction conditions. Industrial Kraft lignin have glass transition temperatures around $140{ }^{\circ} \mathrm{C}$, whereas decomposition studies at high temperatures show the presence of multiple peaks at $452{ }^{\circ} \mathrm{C}$ with two shoulders at $432{ }^{\circ} \mathrm{C}$ and $482{ }^{\circ} \mathrm{C}$. This is a big difference from lignosulfonates since they have no glass transition temperature, also possessing a low decomposition temperature due to their high carbohydrate content.

\subsection{Soda (or Alkali) lignin}

a. Overview: The pretreatment method using alkaline reagent had emerged as one of the most viable process options[44-45] mainly due to its strong pretreatment effect and relatively simple process scheme. The main features of alkaline pretreatment are that it selectively removes lignin without degrading carbohydrates, increasing porosity and surface area. It has been used traditionally for non-wood fibers such as straw, sugar cane or bagasse[46-47]. Such materials have played a key role as pulp resource for a long time and still remain for some developing countries (China, India and South American countries). Pulps made by soda process are mainly used to make different type of paper and to fabricate packages. The installations for this process have small capacity due to the volume of raw materials, and do not work optimally throughout the year. The technology developed for installations producing pulp from wood, black liquor processing (energy source) or chemical pulp recovery are not adjustable to these small installations. Lignin recovery is one of alternatives proposed to manage black liquors coming from this process, which reduces by 
$50 \%$ the chemical oxygen demand and generates revenue to the plant from use an effluent.

b. Process: Alkaline pretreatments are carried out under milder conditions, less than $160{ }^{\circ} \mathrm{C}$, some of them even at ambient temperature, as evidenced by soaking in sodium hydroxide, or in ammonium hydroxide. Such methods can eliminate the need for expensive materials and special designs to cope with corrosion and severe reaction conditions. It is also possible to recover and reuse chemical reagents in some of the alkaline pretreatment methods[48]. There are many similarities between soda pulp process and Kraft pulp process, especially reactions such as the breaking of bonds between lignin and carbohydrates, lignin depolymerization and itself re-condensation. Unlike the Kraft process, soda pulping black liquor does not contain strong nucleophiles (such as sulfides or hydrosulfides) that could block the condensation of fragmented intermediates. Therefore, the condensation of lignin may be more frequent in this process that in Kraft process. Soda lignin recovery is based on acid precipitation and adjusting other process variables. The industrial process to recover soda lignin from black liquors (derived from wood residual), proceeds by a reduction in the $\mathrm{pH}$ with a mineral acid to a slurry of lignin, which is then filtered, washed and dried, to produce powdered lignin with a high purity and a moisture below $5 \%[49]$.

Table 2. General characteristics of different types of commercial lignins. Adapted from Ref. [52]. (determined by size exclusion chromatography). These lignins exhibit glass transition temperatures between 158$185{ }^{\circ} \mathrm{C}$. The absence of sulfur gives advantage over Kraft lignin in applications that need heat flows and the volatile sulfur compound emissions are undesirable.

\subsection{Organosolv lignin.}

The Organosolv process uses an organic solvent as delignifying agent and is one of the most promising alternatives to existing pulping technologies. It provides cellulose and a solution which, in accordance with traditional designations, can be named "liquor" and contains hemicellulose degradation products and dissolved lignin, both sulfur-free[51]. Because it is obtained with a less aggressive process, Organosolv lignin differs from other lignin types provided by conventional chemical methods. Structurally, it contains more phenol hydroxyls and carbonyl groups, which lead to more oxidized forms (Hibbert ketones). Delignification process with organic solvents can be catalyzed in basic or acidic medium, but may also be carry out in the absence of catalysts, and requiring higher temperatures in this case. Delignification mechanism in basic medium proceeds via ether bonds break $\beta-\mathrm{O}-4$, while the process in acid medium takes place by breaking of ether bonds $\alpha-\mathrm{O}-4$. Organosolv lignin contains hemicellulose amounts between 0.9 to $4.3 \%$, low amounts polysaccharides (sugars) 4.5-5.3\%, and their molecular weights are in the range of 3,960 to $4,340 \mathrm{~g} \cdot \mathrm{mol}^{-1}[52]$.

\begin{tabular}{|l|c|c|c|c|}
\hline \multicolumn{1}{|c|}{ Parameters } & Sulfite lignin & Kraft lignin & Soda lignin & Organosolv lignin \\
\hline Ash (\%) & $4.0-8.0$ & $0.5-3.0$ & $0.7-2.3$ & 1.7 \\
\hline Moisture (\%) & 5.8 & $3.0-6.0$ & $2.5-5.0$ & 7.5 \\
\hline Carbohydrates (\%) & - & $1.0-2.3$ & $1.5-3.0$ & $1.0-3.0$ \\
\hline Acid solubility (\%) & - & $1.0-4.9$ & $1.0-11$ & 1.9 \\
\hline Nitrogen (\%) & 0.02 & 0.05 & $0.2-1.0$ & $0.0-0.3$ \\
\hline Sulphur (\%) & $3.5-8.0$ & $1.0-3.0$ & 0.0 & 0.0 \\
\hline Molecular mass & $1,000-50,000$ & $\begin{array}{c}1,500-5,000 \\
\text { (to 25,000) }\end{array}$ & $\begin{array}{c}1,000-3,000 \\
\text { (to } 15,000)\end{array}$ & $500-5,000$ \\
\hline Separation methods & Ultrafiltration & $\begin{array}{c}\text { Precipitation } \\
\text { (pH change) and } \\
\text { ultrafiltration }\end{array}$ & $\begin{array}{c}\text { Precipitation } \\
\text { (pH change) and } \\
\text { ultrafiltration }\end{array}$ & $\begin{array}{c}\text { Extraction by } \\
\text { organic solvents }\end{array}$ \\
\hline
\end{tabular}

c. Properties: soda lignin is significantly different of lignosulfonates. It has low molecular weight, it is water insoluble, and is obtained with low levels of contaminants (i.e. sugars). Those lignins have more similarities with Kraft lignins (i.e. molecular weight and hydrophobicity) than lignosulfonates. Soda lignins are the only type of commercially available lignin sulfur-free and therefore can be considered the closest to natural[50]. Sugar content has been reported in about 2-3\% (predominantly pentose, although depends of raw material source), while nitrogen content is around $0.8-1.6$, which is relatively high compared to wood lignins. Soda lignins show hydroxyl group content in the range of 4.4 to $5.0 \mathrm{mmol} \cdot \mathrm{g}^{-1}$, whereas the molecular weight distribution is in the range of $6,900-8,500$
Besides, Organosolv lignin has a lower glassy transition temperature $\left(T_{\mathrm{g}}\right)$ and is therefore easier to process terminally than Kraft lignin. The advantages of Organosolv lignin (i.e. an increased fluidity index and easier feeding to oven and boiler combustion chambers) make it attractive as a thermal fuel. Organosolv lignin contains little ash relative to other types of industrial lignin (i.e. Kraft lignin, which is obtained chemically) and it is therefore easier to burn[53].

Table 2 shows principal characteristics for the abovedescribed lignin-types, commercially available[54]. 


\section{LIGNIN AS A SOURCE OF CHEMICALS}

Lignin is an abundant source of renewable raw materials with applications and future prospects fairly good. Paper industry produces huge amounts of lignin annually, and about $98 \%$ of this material is burned directly at the same factories for energy recovery. Approximately $1000000 \mathrm{ta}^{-1}$ sulfite lignin and less than 100,000 ta ${ }^{-1}$ Kraft lignin are commercially exploited. However, over the next few years this will be a promising field for development of products with high added value[55]. Figure 5 presents a summary of the main processes for lignin depolymerization to produce higher value-added compounds.

Lignin may have direct applications such as those presented by lignosulfonates nonhazardous compounds with applications as pesticide dispersants, emulsifiers and heavy metal capturing. Besides, lignin (without any chemical modification process) can be used as copolymer for incorporation into phenol-formaldehyde resins, polyolefinlignin polymers, polyesters-lignin polymers, polyurethaneslignin polymers, etc. So also, lignin may be chemically modified (i.e. phenolization, demethylation, etc.) to be incorporate in formulations to improve performance properties of resins or adhesives[56-58].

Hydrolysis and redox (oxidation or hydrogenation) reactions of lignin at high pressures and temperatures yield low molecular weight compounds. These compounds represent a variety of chemical products with high addedvalue, being the most important group phenolic compounds, such as vanillin, cresols, catechol, and guaiacol, among others[59]. Although biological treatments are also going to be mentioned in the text, this review is mainly dedicated to the chemical treatments than the biological ones. In the next sections, redox, acid/base, thermal and biological processes for depolymerization of lignin will be described, mainly highlighting those using homogeneous or heterogeneous catalytic systems.

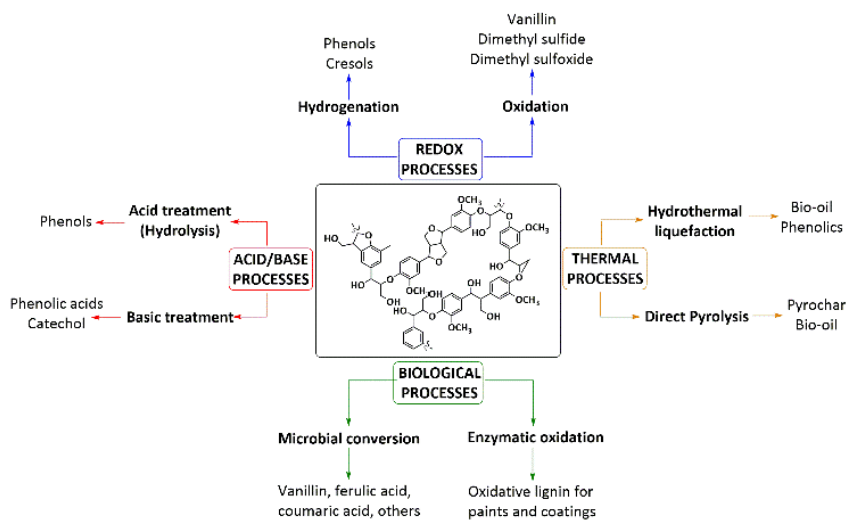

Figure 5. Representative scheme of several processes for lignin transformation.

\subsection{Redox processes.}

a. Oxidative depolymerization: In the recent years oxidative depolymerization has attracted more and more attention due to the easier transition to the industry, since oxidative methods are already widely employed in the papermaking industry for pulp bleaching[60]. In addition, oxidative methods may work under mild reaction conditions achieving high selectivity when an appropriate catalytic system is used, and also avoiding the problems of overoxidation[61]. However, performing oxidative methods increases the number of the functionalities in lignin, thus driving to a more complex mixture and making harder its further analysis. Also, this process usually involves radicals formation which could react between them, thus conducting to a re-polymerization of lignin[62]. Therefore, an efficient oxidative system has to be able to perform a selective oxidation, under mild conditions, getting fine chemicals bearing moieties such as aldehydes or carboxylic acids, easy to analyze. Figure 6 shows a schematic model for the oxidative depolymerization of lignin.

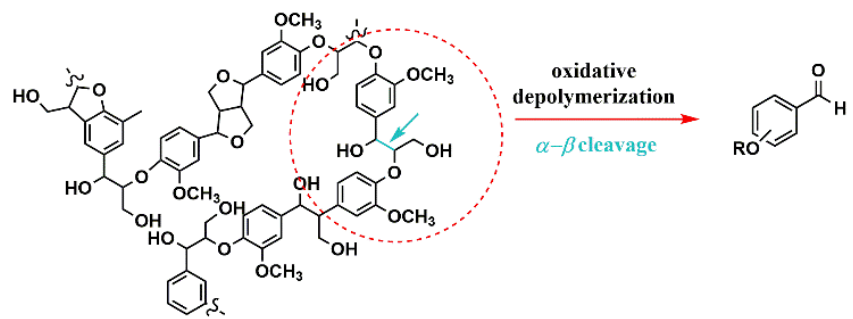

Figure 6. Schematic model of the oxidative-cleavage of lignin.

Focusing on heterogeneous catalysts, as they are the more convenient thinking on an industrial application, that would the last objective on this field, there are some systems able to perform a selective oxidative depolymerization of lignin. Perovskite-type oxides were widely used since their high activity in the catalytic oxidation of hydrocarbons. L. Lin and co-work. showed that $\mathrm{LaMnO}_{3}$ and $\mathrm{LaCoO}_{3}$ materials are highly active and robust non-noble metal catalysts for the catalytic wet aerobic oxidation (CWAO) of lignin to aromatic aldehydes[63-64]. In these works the authors describe how lignin conversion and selectivity were enhanced compared with the non-catalytic process, while insights on the reaction mechanism were provided by XPS studies. The catalysts shown to be robust after more than five re-uses. Figure 7 shows the Lignin conversion and yields of aromatic aldehydes when no catalyst was added (0) and when catalyst was re-used five successive times during $50 \mathrm{~min}$. The authors has also found that the addition of $\mathrm{Cu}$ in the catalyst enhanced the selectivity of the reaction, especially towards $p$-hydroxybenzaldehyde, vanillin, and syringaldehyde, respectively[64].

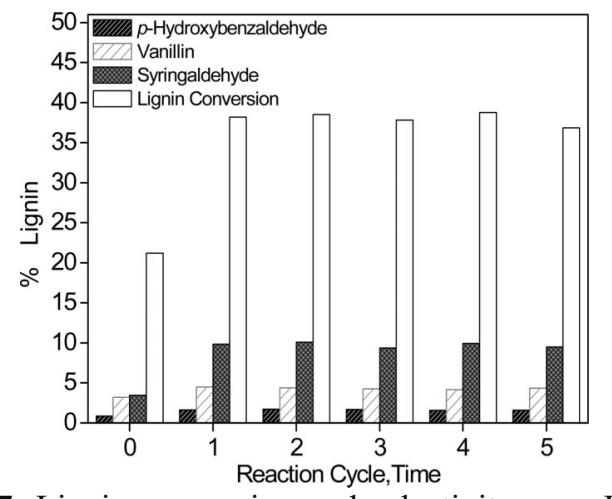

Figure 7. Lignin conversion and selectivity over $\mathrm{LaMnO}_{3}$ catalyst after five successive runs. Reprinted with 
permission from Ref. [63]. Copyright 2009 American Chemical Society.

After that, new methods using La-based materials have been developed. For example, X. Gu et al. have reported an environmental friendly microwave assisted method using La-SBA-15 as heterogeneous catalyst with $\mathrm{H}_{2} \mathrm{O}_{2}$ as oxidant in water, getting high selectivity to Syringaldehyde ( $\geq 18 \%$ )[65]. Catalytic oxidation with oxygen and $\mathrm{H}_{2} \mathrm{O}_{2}$ was suggested as an efficient method for lignin degradation in industrial pulping technologies such as delignification/bleaching, treatment of effluents, and fabrication of aromatic compounds; therefore, these methods have been extensively studied in recent years. For example, lignins have been oxidized under alkaline conditions, in the presence of $\mathrm{Pd} / \gamma-\mathrm{Al}_{2} \mathrm{O}_{3}[66]$ as well as using $\mathrm{Cu}$ and $\mathrm{Co}$ salts to give aromatics aldehydes[67]. In addition, a very original method was lately described[68] using cheap metals as catalysts, mixed oxides based on $\mathrm{CuFeO}$, using an aqueous neutral medium under relatively low pressure. Authors demonstrated how selectivities and conversion strongly depend on temperature and reaction time. As a model, they studied the oxidative-cleavage of lignin-derived dimer, reaching selectivity up to $85 \%$ of benzoic acid (Figure 8) at conversions close to $100 \%$. Reaction mechanism was studied as well; it was found that $\mathrm{O}_{2}$ could be mainly responsible for the first ether bond $\mathrm{R}-$ $\mathrm{O}-\mathrm{R}^{\prime}$ cleavage giving vanillin and benzyl alcohol products.

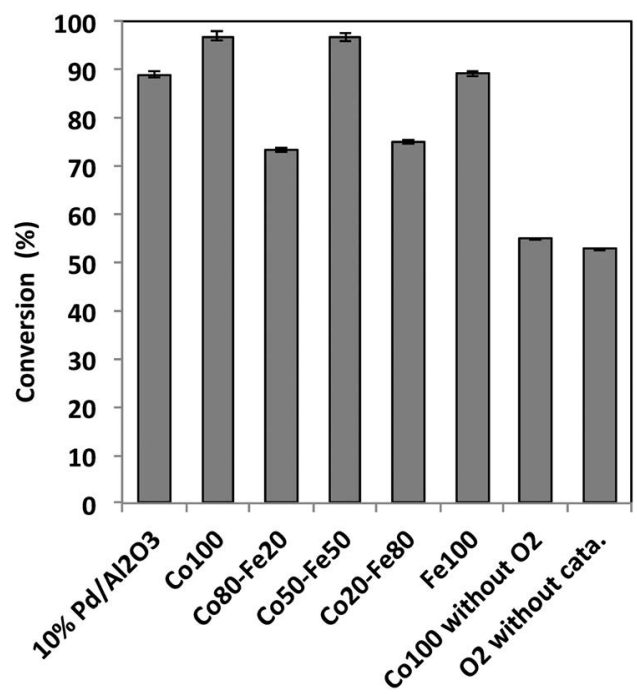

Figure 8. Lignin-derived dimer conversion with different catalysts. Reprinted with the permission from Ref. [68]. Copyright 2018, Royal Society of Chemistry.

An important family of compounds used in the oxidativecleavage of lignin are transition metal-containing hydrotalcite-type materials. They were used for various authors as catalysts in the cleavage of lignin model compounds and different lignin sources. Copper-vanadium and copper-vanadium-zinc hydrotalcite as catalysts (HTc$\mathrm{Cu}-\mathrm{V}$ and $\mathrm{HTc}-\mathrm{Zn}-\mathrm{Cu}-\mathrm{V}$ ) working in pyridine showed high activity and good selectivity for the cleavage of erythro-1,3dilignol[69]. Veratric acid (64\% yield) was the main product, while veratraldehyde was obtained in $8 \%$ yield[69]. Lignin cleavage studies with different
Organosolv and Kraft lignin sources showed that HTc-Cu-V completely degraded the $\beta-\mathrm{O}-4$ and the protected $\beta-\mathrm{O}-4$ linkages, as well as the resinol structures and phydroxycinnamyl alcohol motifs present in the lignin sources. Furthermore, Beckham and co-workers showed that HTC-based materials are effective catalysts for lignin depolymerization. They showed that the use of HTCs containing intercalated $\mathrm{NO}^{3-}$ anions increase activity by two-three times for some model compounds, but some accompanying basicity is required for maximum activity, yielding $8 \%$ of syringaldehyde and $10 \%$ of 4-allylsyringol, respectively[70].

Excellent reviews summarize the oxidative depolymerization of lignin up to 2015[71-72].

b. Reductive depolymerization (hydrogenation): Lignin depolymerization by hydrogenolysis/hydrogenation consists in subjecting lignin to reduction in the presence of $\mathrm{H}_{2}$ (reaction at moderate to high pressures and temperatures). The reaction systems generally use water as solvent and a catalyst with hydrogenating properties. Under these conditions, lignin bonds suffer structural breakdown by hydrogenolysis. This process is commonly accelerated by the addition of external acids. The process can be conducted in one or two stages obtaining as products aromatics compounds and highly hydrogenated hydrocarbons. This approach is more attractive than the oxidative depolymerization, since the stepwise reductive deoxygenation (and even hydrodeoxygenation) of the aromatic monomers obtained after depolymerization generally leads to a decrease of complexity in the product mixtures, increasing the selectivity to defined aromatic compounds. A schematic model of this reaction is shown in Figure 9.

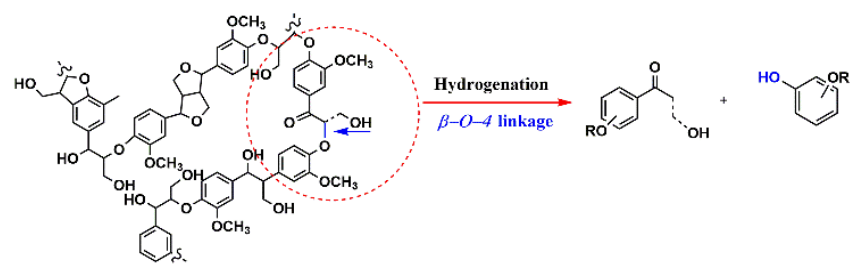

Figure 9. Schematic model of the hydrogenolysis/hydrogenation of lignin.

N. Yan et al.[73] have described a two-stage process (hydrogenolysis/hydrogenation) for lignin conversion into hydrocarbons and methanol. The first step involves a transformation system in acidic medium (aqueous and/or organic, solvent: dioxane) using $\mathrm{Pt} / \mathrm{C}$ or $\mathrm{Rh} / \mathrm{C}$ as catalysts at $474 \mathrm{~K}$ and $4 \mathrm{MPa}$ of $\mathrm{H}_{2}$. Best results were obtained using $\mathrm{H}_{3} \mathrm{PO}_{4}(1 \mathrm{wt} \%$ in water) in dioxane $(50 \%)$ and $\mathrm{Pt} / \mathrm{C}$ catalyst, with yields of $46 \%$ and $12 \%$ to monomers and dimers, respectively. In a second step, products obtained above were converted into alkanes and methanol with quantitative yields using $\mathrm{H}_{2}$ and $\mathrm{Pd} / \mathrm{C}$. Final yields achieved was $90 \%$ for C8-C9 fraction and $82.3 \%$ for C14-C18[73]. Hydrogen required for this process can be generated in situ by promoters (or hydrogen donors) as formic acid or methanol, method that has attracted attention of many investigators, 
since it is a way to decrease the amount of waste generated[74-75].

Following this strategy, it has been reported a process for lignin depolymerization in a closed system in presence of formic acid, an alcohol and in absence of any catalysts resulting in the complete conversion of macromolecular structure of lignin into a complex mixture of low molecular mass compounds. Most of these products are aliphatic hydrocarbons and a substantial number of aromatic compounds. These results are indicative that formic acid is a good in situ hydrogen generator[14]. Similarly, a process using formic acid as hydrogen donor, without catalyst, in supercritical conditions (at $370{ }^{\circ} \mathrm{C}$, and 100 bar during 3.5 hours) with carbon dioxide/acetone/water as solvent mixture has been described. This process has been applied to Organosolv lignin obtained from two different raw material types, and syringol and syringic acid were determined as major products. Liquid fraction yield attained was $20.3 \mathrm{wt} \%$ while ash accounted 51.5wt $\%$, for total weight converted[76].

Methanol is another hydrogen donor commonly utilized in supercritical conditions. In this sense, by using a copper doped hydrotalcite $(\mathrm{Cu}-\mathrm{PMO})$ as catalyst a complex mixture of monomeric compounds was obtained, where major products were cyclohexyl derivatives $(86 \mathrm{wt} \%)$ [77].

In addition, a two stage process for lignin conversion into high quality gasoline has been reported[78-79]. First stage involves lignin depolymerization process by using bases (preferably $\mathrm{NaOH}$ ), alcohols as solvent and supercritical medium (320 ${ }^{\circ} \mathrm{C}, 120$ bar). Second stage consists in a hydrogenation process for lignin depolymerization to generate finally naphthenic and paraffinic hydrocarbons. Catalysts used in this second step are NiMo or CoMo sulfides supported on $\gamma$-alumina (standard hydrotreating catalysts). Alternatively, depolymerization products can be converted into alkyl-aryl ethers by feeding them into a selective hydrocracking reactor using a solid super-acid catalyst $\left(\mathrm{Pt} / \mathrm{SO}_{4} / \mathrm{ZrO}_{2}\right.$ or $\left.\mathrm{Pt} / \mathrm{WO}_{4} / \mathrm{ZrO}_{2}\right)$ at $340-375{ }^{\circ} \mathrm{C}$. Besides, phenols can be subjected to an etherification reaction using in situ mixed catalysts based on zirconia-type materials $\left(\mathrm{WO}_{4} / \mathrm{ZrO}_{2}\right.$ or $\left.\mathrm{SO}_{4} / \mathrm{ZrO}_{2}\right)$ in the presence of methanol at $225-275{ }^{\circ} \mathrm{C}$.

More recently, Román-Leshkov et al. have carried out a complete study on the selective depolymerization of lignin from vanilla seeds using $\mathrm{Ni} / \mathrm{C}$ as catalysts, making a comparison between theoretical and experimental approaches[80]. In this case, only propyl- and propenylcatechol were generated as main products. More interesting an etherification-hydrogenolysis method was applied in the depolymerization of raw Beech hardwood sawdust by $\mathrm{Xu}, \mathrm{J}$. et al. [81], using $\mathrm{Ni} / \mathrm{C}$ as catalyst in $\mathrm{MeOH} / \mathrm{H}_{2} \mathrm{O}$ at $200{ }^{\circ} \mathrm{C}$, 20 bar $\mathrm{H}_{2}$. Two natural phenolic alcohols syringylpropanol and guaiacylpropanol were obtained as main products, yields of $26.6 \%$ and $9 \%$ respectively. Besides, C1-C3 alkylsyringols and alkylguaiacols, like propylsyringol and propylguaiacol, were identified as other phenolic monomers.
UPM-Kymmene Corporation has recently claimed a ruthenium-based catalyst supported on zirconium oxide, used for the depolymerization of lignin by hydrotreating under moderate reaction conditions (i.e. $250{ }^{\circ} \mathrm{C}$ and 22 bar of $\mathrm{H}_{2}$ ). According to researchers, the catalyst supported on $\mathrm{ZrO}_{2}$ which mainly possesses monoclinic phase achieved better performance and yields to phenolic monomeric compounds in organic phase[82]. The process developed is applicable to different types of lignin dissolved in aqueous phase or in water/ethanol mixture, the process is notable for carrying out in a single reactor (one-pot), both stages: depolymerization and hydrodeoxygenation. This process reached good organic phase yields above $50 \%$, these results are comparable to those obtained with a commercial catalyst that contains more than twice ruthenium content $(5 \mathrm{wt} \%$ $\mathrm{Ru} / \mathrm{C})$. Guaiacol, vanillin and acetovanillone were the main products identified in the organic phase mixture[83-84].

Another interesting catalytic system was developed by the B. F. Sels research group[85], where they convert lignocellulosic biomass into a mixture of hemicellulose, cellulose and lignin easy to separate by the use of a mixture of $\mathrm{BuOH}$ and $\mathrm{H}_{2} \mathrm{O}$ as solvent, at high temperatures $\left(200{ }^{\circ} \mathrm{C}\right)$ and using $\mathrm{Ru} / \mathrm{C}$ as catalyst. Furthermore, one-pot depolymerization was also performed in this work, getting maximum yields $(40 \%)$ of lignin monomers derivatives. The monomer distribution achieved in each solvent phase employed is shown in Figure 10.

Lignin-derived monomers ( $n$-butanol phase)
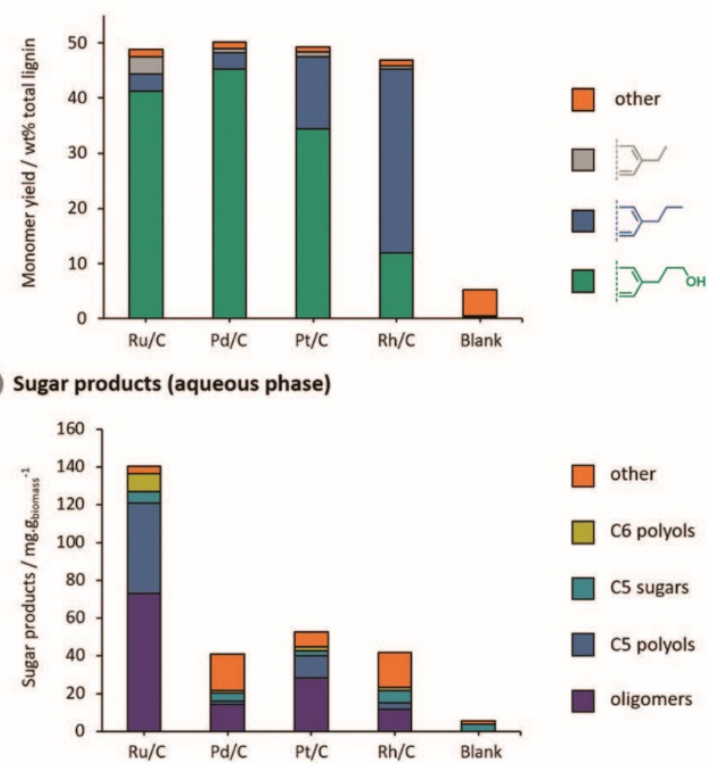

Figure 10. (A) Lignin monomers and (B) carbohydrate products obtained from RCF process in n-butanol/water with different catalysts. Reaction conditions: $20 \mathrm{~mL} n-$ butanol, $20 \mathrm{~mL}$ water, $2 \mathrm{~g}$ pre-extracted eucalyptus sawdust, 0.2 g catalyst, 30 bar $\mathrm{H}_{2}, 200{ }^{\circ} \mathrm{C}, 2 \mathrm{~h}$. Reprinted with the permission from Ref. [69]. Copyright 2018, Royal Society of Chemistry.

EtOH was effectively used as solvent in the reductive depolymerization of lignin[86]. Many authors studied its effects in the degree of depolymerization, showing a very high potential to become a green solvent in this field. Citing 
some of the most effective system, $88.1 \mathrm{wt} \%$ of bio-oil was obtained using $\mathrm{Ru} / \mathrm{C}$ as catalyst and $\mathrm{MgO}$ as cocatalyst[87]. Kuznetsov et al. investigated the effects of sulfated metal oxides, i.e. $\mathrm{ZrO}_{2}$, supported $\mathrm{Al}_{2} \mathrm{O}_{3}$ catalysts, and acidic zeolite catalysts for the hydrogenolysis of alkali lignin from Aspen wood in ScEtOH at $350{ }^{\circ} \mathrm{C}$ and $400{ }^{\circ} \mathrm{C}$. Conversion of lignin reached was about $62.5 \mathrm{wt} \%$ of bio-oil including esters, phenols, aldehydes among others alkanes[88].

Table 3 summarizes the most significant contribution for both types of processes, oxidation and hydrogenation of lignin.

Table 3. Summary of references on oxidation and hydrogenation of lignin from 2000 to 2018 years discussed in this review. of many phenolic molecules indicates that lignin fragmentation reaction does not play a main role during the decomposition reactions of lignin structure. Moreover, aromatic rings can be alkylated in significant amount to produce heavy condensation compounds, while the ether bounds are more easily broken than the $\mathrm{C}-\mathrm{C}$ bounds.

Main phenolic compounds, including catechol, phenol, m-, $\mathrm{p}$ - and o-cresol were obtained from liquid fraction of lignin liquefaction products, which are important intermediates in pharmaceutical and chemical industry, being HTL a sustainable method to recover these chemicals. Zhang et al. performed the HTL of lignin extracted from aspen wood getting 90\% yield of liquid being almost all phenolic compounds[93]. Compressed water was used for X. Chumbao et al. to get phenolic compounds with a high yield[94]. The liquefaction operations at $250{ }^{\circ} \mathrm{C}$ during

\begin{tabular}{|c|c|c|c|c|}
\hline Entry & Catalyst & Reaction conditions & Main Products & Reference \\
\hline \multicolumn{5}{|c|}{ OXIDATIVE DEPOLIMERIZATION OF LIGNIN } \\
\hline 1 & 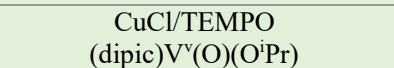 & $\begin{array}{c}\mathrm{O}_{2}, 100^{\circ} \mathrm{C}, \text { pyr- } \mathrm{d}_{5}, 48 \mathrm{~h} \\
\text { Air, } 100^{\circ} \mathrm{C}, \text { DMSO-d } \\
6\end{array}$ & $\begin{array}{l}\text { Benzaldehyde, methylbenzoate } \\
\text { Benzoic acid, methylbenzoate }\end{array}$ & [61] \\
\hline 2 & $\mathrm{LaCoO}_{3}$ & 5 bar $\mathrm{O}_{2}, \mathrm{NaOH} 2 \mathrm{~mol} / \mathrm{L}, 120^{\circ} \mathrm{C}, 3 \mathrm{~h}$ & Vanillin, aldehydes & [63] \\
\hline 3 & $\begin{array}{l}\mathrm{LaCo}_{1-\mathrm{x}} \mathrm{Cu}_{\mathrm{x}} \mathrm{O}_{3} \\
(\mathrm{x}=0,0.1,0.2)\end{array}$ & 5 bar $\mathrm{O}_{2}, \mathrm{NaOH} 2 \mathrm{~mol} / \mathrm{L}, 120^{\circ} \mathrm{C}, 3 \mathrm{~h}$ & Vanillin, aldehydes & [64] \\
\hline 4 & La-SBA-15 & $\begin{array}{l}\text { Microwave radiation } 200 \mathrm{~W}, \mathrm{H}_{2} \mathrm{O}_{2}\left(35 \mathrm{wt} \% \mathrm{H}_{2} \mathrm{O}\right) \\
\text { Alkaline solution }(\mathrm{pH}=13-14), 60{ }^{\circ} \mathrm{C}, 30 \mathrm{~min}\end{array}$ & Vanillin, aldehydes, siryngic acid & [65] \\
\hline 5 & $\begin{array}{c}{\left[\mathrm{SiW}_{11} \mathrm{Mn}^{\text {III }}\left(\mathrm{H}_{2} \mathrm{O}\right) \mathrm{O}_{39}\right]^{5-}} \\
\operatorname{SiW}_{11} \mathrm{Mn}^{\text {III }}\end{array}$ & 30 bar $\mathrm{O}_{2}, \mathrm{pH}=4-5,110^{\circ} \mathrm{C}, 2 \mathrm{~h}$ & acids & [66] \\
\hline 6 & $\begin{array}{l}\text { Mn substituted polyoxotungstates } \\
\text { of Keggin type }\end{array}$ & 50 bar $\mathrm{O}_{2}, \mathrm{pH}=4-5,110^{\circ} \mathrm{C}, 2 \mathrm{~h}$ & & [67] \\
\hline 7 & CoFeO mixed oxides & $10 \% \mathrm{O}_{2} / \mathrm{N}_{2}, \mathrm{H}_{2} \mathrm{O} \mathrm{pH}=7,150-200{ }^{\circ} \mathrm{C}, 4 \mathrm{~h}$ & Benzoic acid, alkyl benzene & [68] \\
\hline 8 & $\mathrm{HTC}-\mathrm{NO}_{3}$ & MIKB, air, $275^{\circ} \mathrm{C}, 1 \mathrm{~h}$ & 4-Vinylphenol, vanillin, aldehydes & [70] \\
\hline \multicolumn{5}{|c|}{ REDUCTIVE DEPOLIMERIZATION OF LIGNIN } \\
\hline 9 & $\mathrm{Pt} / \mathrm{C}$ & $\mathrm{H}_{2} \mathrm{O}, \mathrm{H}_{3} \mathrm{PO}_{4}, 40$ bar $\mathrm{H}_{2}, 200{ }^{\circ} \mathrm{C}$, , $4 \mathrm{~h}$ & Guaiacyl propane, syringyl propane & [73] \\
\hline 10 & $\mathrm{Cu}_{2} \mathrm{O}-\mathrm{PMO}$ & $\mathrm{MeOH}, 300{ }^{\circ} \mathrm{C}, 13 \mathrm{~h}$ & Alcohols, dihydrobenzofuranes & [75] \\
\hline 11 & - & $\mathrm{CO}_{2} /$ acetone $/ \mathrm{H}_{2} \mathrm{O}, 300-370{ }^{\circ} \mathrm{C}, 100$ bar $\mathrm{H}_{2}$ & Aromatics & [76] \\
\hline 12 & $\mathrm{Cu}-\mathrm{PMO}$ & $\mathrm{MeOH}, 300^{\circ} \mathrm{C}, 30 \mathrm{~min}$ & Alkenes & [77] \\
\hline 13 & $\mathrm{Ni} / \mathrm{C}$ & $\mathrm{MeOH}, 30$ bar $\mathrm{H}_{2}, 200-250{ }^{\circ} \mathrm{C}, 3-16 \mathrm{~h}$ & Propyl catechol among others alkenes & [80] \\
\hline 14 & $\mathrm{Ni} / \mathrm{C}$ & $\mathrm{MeOH} / \mathrm{H} 2 \mathrm{O}, 20$ bar $\mathrm{H}_{2}, 5 \mathrm{~h}$ & Syringol and guaiacol derivatives & [81] \\
\hline 15 & $\mathrm{Ru} / \mathrm{ZrO}_{2}$ & $\mathrm{H}_{2} \mathrm{O}$ (or $\left.\mathrm{H}_{2} \mathrm{O} / \mathrm{EtOH}\right), 22$ bar $\mathrm{H}_{2}, 250^{\circ} \mathrm{C}$ & Guaiacol, vainillin, acetovainillone & [83-84] \\
\hline 16 & $\mathrm{Ru} / \mathrm{C}$ & $\mathrm{H}_{2} \mathrm{O} / \mathrm{ButOH}, 200{ }^{\circ} \mathrm{C}$ & Lignin monomers derivatives & [85] \\
\hline
\end{tabular}

4.2 Thermal processes: In this section, two thermal processes related to the treatment of lignin feedstocks at high temperatures, and referred as: a) hydrothermal liquefaction (performed at $200-550{ }^{\circ} \mathrm{C}$ in the presence of solvent, including water), and b) direct pyrolysis (at 550$1000{ }^{\circ} \mathrm{C}$ in the absence of solvents) will be discussed.

a. Hydrothermal liquefaction (HTL): Hydrothermal liquefaction has been widely applied to obtain bioenergy and high added-value chemicals from biomass in the presence of a solvent at moderate to high temperatures $\left(200-550^{\circ} \mathrm{C}\right)$ and pressures $(5-25 \mathrm{MPa})[89]$. The main products obtained through this treatment are bio-oil and mainly phenolic-type compounds[90]. It is consider as an environmental friendly treatment due to its short holding time, high conversion rate and less secondary products. All of the reactions that occur during HTL, such as hydrolysis, cleavage of the $\mathrm{C}-\mathrm{O}-\mathrm{C}$ and $\mathrm{C}-\mathrm{C}$ bonds, and condensation, compete against each other during the process for phenolic compounds production[91], thus being able to form a huge variety of compound as it is shown in Figure 11. Therefore, the characterization of the final mixtures play a key role in this process[92]. In the liquefaction process, the formation
60 min produced the desirable product of phenolic/neutral oil in yields of about $53 \%, 32 \%, 32 \%$ and $17 \%$ with respect to the initial mass fed of lignin, sawdust, cornstalk and cellulose, respectively. The yields of phenolic/neutral oil could be significantly enhanced by the addition of $\mathrm{Ba}(\mathrm{OH})_{2}$ and $\mathrm{Rb}_{2} \mathrm{CO}_{3}$ catalysts for all feedstocks, except for lignin. In the work of J. Chang et al., the liquefaction of alkaline lignin is shown, and the obtained liquid mixture is then separated into four main type of substances: benzenediols, monophenolic hydroxyl products, weak-polar products, and water-soluble products (low-molecular-weight organic acids, alcohols, etc.). From the yields achieved, more than half of the oil products consisted of phenolic molecules. A mechanism for phenolics production is also proposed via decomposition of lignin under hydrothermal conditions occurring mainly by three steps: hydrolysis and cleavage of the ether bond and the $\mathrm{C}-\mathrm{C}$ bond, demethoxylation, and alkylation[95]. In another example, coniferyl alcohol was obtained with $92 \%$ of yield using Ni-based catalysts under $\mathrm{H}_{2}$ atmosphere through the HTL treatment of Kraft lignin. 


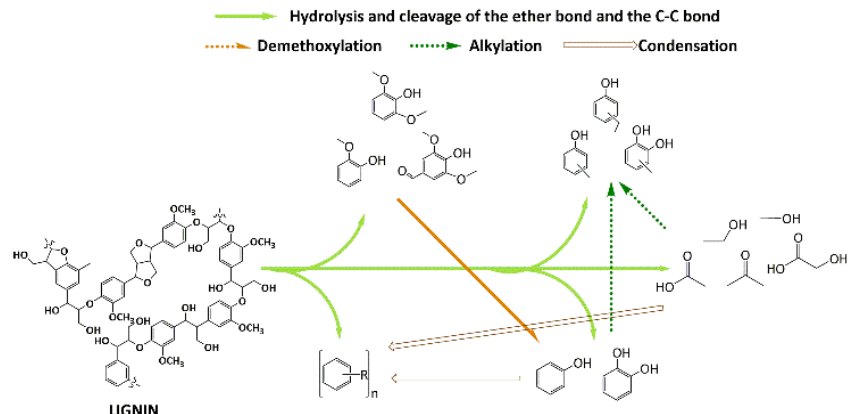

Figure 11. Proposed mechanisms of lignin hydrothermal liquefaction. Adapted and reprinted with the permission from Ref. [70]. Copyright 2018, Elsevier.

In general, all the above-mentioned research works demonstrate the importance that the source of lignin has in the final distribution obtained after a HTL treatment[95]. In these sense, organic acids are another important products achieved from lignin hydrothermal liquefaction process. The production of these acids comes from the decomposition of the phenyl propane units, while benzene structure remains quite stable during the treatment[96]. Although lignin demonstrates to be a natural reserve with high potential for aromatics production, the HTL degradation of lignin has not reached the expected industrial scale mainly because of the difficulty of the methodology itself, and the subsequent products separation. Nevertheless, laboratory scale studies have succeeded in the lignin conversion, where $60 \mathrm{wt} \%$ low-molecular-weight aromatics from oxidized-type lignin[97] or almost quantitative yields of guaiacyl and syringyl monomers from a soluble lignin fraction[98] were achieved. However, further improvements in current chemical and separation methods are needed to achieve effective, simple, and environmentally friendly strategies for the production and recovery of aromatic monomers from lignin via HTL processes[99].

b. Direct Pyrolysis: Pyrolysis is a treatment performed at high temperature without using any solvents and in the absence of oxygen to ensure that there is no further oxidation to $\mathrm{CO}_{2}$. This thermal treatment could be conducted with or without catalysts. Pyrolysis converts lignin into solid char, liquid oil, and gases, the proportion of which depends primarily on the temperature and the heating rate. The action of pyrolysis treatment in the lignin structure was studied by using different model compounds as feed. Thus, the behavior of $\beta-O-4-i n t e r u n i t$ links during pyrolysis was studied using $\beta$-aryl ether-type model compounds including guaiacylglycol- $\beta$-propylphenyl ether, veratrylglycol- $\beta$-propylphenyl ether, guaiacylglycerol- $\beta$ guaiacyl ether, and guaiacylglycerol- $\beta$-syringyl ether. ${ }^{100}$ Such model compounds were observed to undergo the bond cleavages mostly at the $\alpha$-aromatic ring bond, the $\beta$-ether bond and by $\alpha-\beta$-dehydration. Figure 12 shows a schematic model of the cleavage of lignin during pyrolysis. The final products of the neat pyrolysis depend on the severity of the treatment, with the possibility of obtaining simple-lower molecular weight components (i.e. methylguaiacol, vanillin or coniferaldehyde) if the treatment is carried out at high temperatures or at longer contact times.

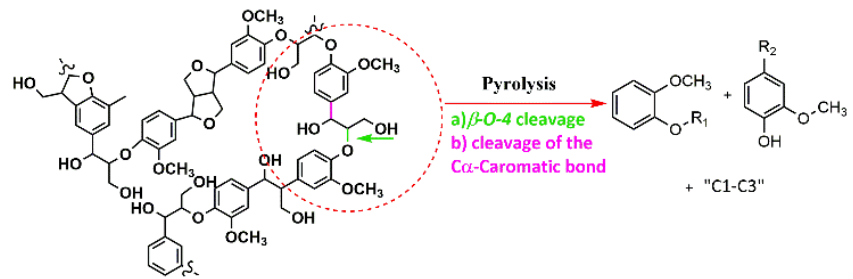

Figure 12. Schematic model of the pyrolysis of lignin.

Catalytic pyrolysis including the use of solid acid or combined acid/base catalysts has also been applied for lignin depolymerization. Pyrolysis of alkaline lignin catalyzed by proton zeolites with different pore size (i.e. HBETA, H-ZSM-5 and H-USY), was studied by van Bokhoven et al.[101-102]. These catalysts possess mainly Brönsted-type acid sites that play a dual role participating in lignin depolymerization but also stabilizing monomers to prevent re-polymerizing. Best results were obtained with $\mathrm{H}$ USY zeolite, with $75 \mathrm{wt} \%$ yield of liquid fraction containing $40 \mathrm{wt} \%$ of aromatic hydrocarbons, such as toluene, xylenes and alkoxy-phenols, among others. Thring et al.[103] investigated the catalytic conversion of lignin isolated from a hardwood mixture at high temperatures range (500$600{ }^{\circ} \mathrm{C}$ ) by using $\mathrm{H}-\mathrm{ZSM}-5$ zeolite as acid catalyst. In this case, high yields to liquid fraction (43wt\%, consisting mostly in toluene, benzene and xylene) were achieved, together with important amounts of coke and ash ranging from 15 to $50 \mathrm{wt} \%$ for both of them. By working at higher temperatures, an increase in gases production is observed accompanied by a decrease in the yields to liquid fraction, coke and ash, respectively.

Table 4. Most representative references of thermal processes of lignin from 2000 to 2018 years discussed in this work.

\begin{tabular}{|c|c|c|c|c|}
\hline Entry & Process & $\begin{array}{c}\text { Reaction } \\
\text { conditions }\end{array}$ & Products & Ref. \\
\hline 1 & \multirow{5}{*}{$\begin{array}{l}\text { Hydrothermal } \\
\text { liquefaction }\end{array}$} & $374^{\circ} \mathrm{C}, 10 \mathrm{~min}$ & $\begin{array}{l}\text { Mixture of } \\
\text { aromatics }\end{array}$ & {$[93]$} \\
\hline 2 & & $\begin{array}{l}\mathrm{H}_{2} \mathrm{O}, 250-350{ }^{\circ} \mathrm{C}, \\
20 \text { bar } \mathrm{H}_{2}, 60 \text { min }\end{array}$ & phenolics & [94] \\
\hline 3 & & $\mathrm{KOH}, 250-450$ & $\begin{array}{l}\text { Catechol, } \\
\text { mixtures of } \\
\text { phenolics }\end{array}$ & {$[95]$} \\
\hline 4 & & $\begin{array}{c}\mathrm{H}_{2} \mathrm{O}, 380{ }^{\circ} \mathrm{C} \\
10000 \text { bar, } 10 \mathrm{~min}\end{array}$ & $\begin{array}{l}\text { Low } \\
\text { molecular } \\
\text { weight } \\
\text { organic } \\
\text { acids }\end{array}$ & {$[96]$} \\
\hline 5 & & $\begin{array}{l}\text { Formic acid, } 110 \\
{ }^{\circ} \mathrm{C}, 24 \mathrm{~h}\end{array}$ & $\begin{array}{l}\text { Low } \\
\text { molecular } \\
\text { weight } \\
\text { aromatics }\end{array}$ & {$[97]$} \\
\hline 6 & \multirow{3}{*}{ Pyrolysis } & $\begin{array}{c}\mathrm{Fe}_{3} \mathrm{O}_{4} @ \mathrm{SiO}_{2} @ \mathrm{Re}, \\
\mathrm{H}_{2} \mathrm{O}, 100-230^{\circ} \mathrm{C}, \\
15 \text { bar } \mathrm{H}_{2}, 1-24 \mathrm{~h}\end{array}$ & $\begin{array}{l}\text { Acetylated } \\
\text { derivatives } \\
+ \text { coke }\end{array}$ & [101] \\
\hline 7 & & $\begin{array}{c}\text { FAU-zeolite, } 650 \\
{ }^{\circ} \mathrm{C}, 20 \mathrm{~s}\end{array}$ & $\begin{array}{l}\text { Phenols, } \\
\text { aromatics }\end{array}$ & [102] \\
\hline 8 & & $\begin{array}{l}\text { HZSM-5, 500-600 } \\
{ }^{\circ} \mathrm{C}, 5 \mathrm{~h}\end{array}$ & $\begin{array}{l}\text { Aromatics, } \\
\text { alcohols, } \\
\text { ketones }\end{array}$ & [103] \\
\hline
\end{tabular}


In general, both thermal and catalytic pyrolysis processes were extensively studied during the latest years as a way to convert lignin into valuable products with a simple and cheap treatment[104]. In spite of these studies, they are not considered as good treatments to obtain aromatics monomers since the main compounds getting by these treatments are pyrochar and bio-oil. For that reason pyrolysis has not been considered as a main topic to review in this work, mainly focused on the production of aromatics from lignin. A series of comprehensive texts and interesting reviews are published focused on this topic[105-106].

Table 4 summarizes the most significant contribution for thermal processes here described.

\subsection{Acid/base processes:}

a. By acid catalyst: Various lignin depolymerization procedures are grouped in this section based on the use of acid catalysts in the reactive system. These mainly include hydrothermal processes (with water and solid acid and/or redox catalysts) and thermochemical processes (with acidic catalysts in homogeneous systems or ionic liquids).

Recently, it has been reported a new lignin depolymerization combined with phenols isolation. This process is carried out in water and involves a combination of formic acid as hydrogen source (in situ), a palladium supported on a polymeric resin as solid acid catalyst (Nafion SAC-13), by working at $300{ }^{\circ} \mathrm{C}$ during 2 hours. Lignin depolymerization produced a phenols mixture, mainly composed by guaiacol, pyro-catechol and resorcinol, whose yields depended from lignin type studied. Figure 13 shows a GC-MS analysis of reaction products showing a mixture dominated by phenolic compounds[107].

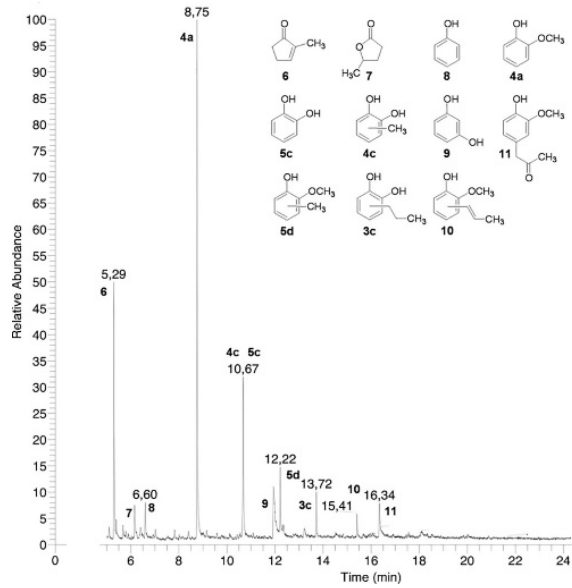

Figure 13. GC-MS of the reaction mixture. Reprint with the permission from Ref. [107]. Copyright 2011, Elsevier

Organosolv lignin type (Alcell) has been depolymerized in batch reactor using Lewis acid catalysts, such as $\mathrm{NiCl}_{2}$ and $\mathrm{FeCl}_{3}$, and the effect of different factors (i.e. temperature, catalyst, and reaction time) on lignin conversion and reaction products (liquid, gas and solid) were studied. Under tested reaction conditions both catalysts favor condensation reactions, thus obtaining low yields to monomers for $\mathrm{Ni}$ $(30 \mathrm{wt} \%)$ and $\mathrm{Fe}(26 \mathrm{wt} \%)$ catalysts, respectively[108].
Ionic liquids are excellent solvents for processing wood biomass and lignin. They provided, for example, a suitable medium for dealkylation reaction of model compounds (i.e. eugenol and 4-ethylguaiacol), and can also be used for commercial lignin depolymerization by acid catalysts. In this regard, Lewis acid catalysts (i.e. iron chloride, cobalt chloride, nickel chloride, lanthanum or scandium trifluoromethanesulfonate, etc.) were inactive for this reaction, whereas Brönsted acid catalysts such as heteropolyacids, protonic zeolites or ion exchange resins showed moderate activity to obtain guaiacol $(11.6 \mathrm{wt} \%$ yield) from eugenol. However, when 4-ethylguaiacol and commercial lignin were essayed practically no conversion was observed in the presence of two acid-type catalysts (Brönsted and Lewis)[109].

Better results were obtained for the purification of lignin using ionic liquids, in this way different kind of lignins extracted from lignocellulosic materials are effectively purified using ionic liquids, getting more than $98 \%$ of purity as for example in the case of Kraft lignin[110]. Furthermore, alkylphenolics and/or cycloalkanes were obtained in a recent work using ionic liquids combined with electrochemical treatment[111]. In this work, lignin model compounds were studied in order to be able to provide a proof of concept. More interesting works about the use of ionic liquids were performed in the latest years, showing thus that the use of ionic liquids provides a "green" approach for the depolymerization of lignin[112-113].

b. By basic catalysts: The reaction of alkaline metal hydroxides with lignin often yields a mixture of simple aromatic compounds under mild reaction conditions. During the base-catalyzed delignification process, $\alpha$-aryl ether bonds are cleaved to form quinone methide intermediate from phenolate-type units[114-115]. Since alkali metal cations form adducts, which act as catalysts for the formation of six-membered transition state over $\beta-O-4$ bonds, the ratio on the concentration of base/lignin/solvent plays a key role in base-catalyzed lignin degradation[116]. As for the acid-catalyzed depolymerization, the nature of base controls the overall percentage yield of bio-oil, in this regard higher yields are expected for strong bases and organic solvents such as phenols and alcohols. The use of strong bases results in large polarization that combined with organic solvents favor solvolysis of ether linkages, thus enriching the kinetics and overall depolymerization reaction mechanism. Lignin thermal hydrolysis in presence of homogeneous basic catalysts (commonly sodium hydroxide) has been reported in various reaction conditions. Labidi and co-work. evaluated the activity of different homogeneous basic catalysts, such as $\mathrm{NaOH}, \mathrm{KOH}, \mathrm{LiOH}$, $\mathrm{K}_{2} \mathrm{CO}_{3}$ and $\mathrm{Ca}(\mathrm{OH})_{2}$, in the Organosolv lignin hydrolysis reaction; best yields were obtained with sodium hydroxide (20wt\% of organic phase), while the rest reported catalysts showed higher selectivity to catechol type monomers. Furthermore, re-polymerization reactions are a predominant factor in this process, evidenced by the presence of residual lignin at the end of the reaction, which in some cases can reach up to $45 \mathrm{wt} \%[117]$. In these systems it was found that the addition of small quantities of boric acid acts as a protective agent via the formation of esters with phenolic 
hydroxyl groups, thus reducing oligomerization and getting high lignin conversions (85wt\%)[118-119]. Depolymerization of Kraft lignin by basic catalysis has been also carried out in a continuous flow reactor by Lavoie et al. demonstrating that sodium hydroxide $(5 \mathrm{wt} \%)$ is a good catalyst for this process. Operating at three different temperatures $\left(270{ }^{\circ} \mathrm{C}, 290{ }^{\circ} \mathrm{C}\right.$ and $\left.315{ }^{\circ} \mathrm{C}\right)$ the authors determined that the highest yield to monomers $(19.1 \mathrm{wt} \%)$ was obtained at $315{ }^{\circ} \mathrm{C}$, and among them the most abundant product was pyrocatechol with a selectivity of $25.8 \%$. Furthermore for all space velocities studied, rising the reaction temperature induces an increase in the gaseous fraction[120]. Deactivation of catalysts is another common problem associated with base-catalyzed depolymerization of lignin that occurs because of the formation of acidic molecules during the process. Furthermore, problems associated to the formation of significant amount of waste during base-catalyzed lignin degradation creates difficulties regarding products isolation[72]. The requirement of high reaction temperature and uncontrolled selectivity of the desired monomeric products make this process up to now non-convenient for an industrial implementation.

\subsection{Biological processes:}

In order to exploit successfully lignin as a renewable source of chemical compounds, the real understanding of the biochemical pathways involved in the decomposition of lignin is needed. For this reason, many researchers have focused their attention into biological processes (degradation pathways) using enzymes as catalysts to depolymerize lignin and get aromatic monomers with various industrial applications. Two main options contemplated for biological treatments will be shortly discussed below.

a. Microbial conversion: Microbial lignin degradation used for the production of biofuels and renewable chemicals starting directly from lignocellulosic plants is a topic of great relevance and under continuous debate. Despite of the extensive research on fungal degradation of lignin, the degradation pathways are still a matter of study due to the high resistance of lignin to decomposition and the complex mixtures finally achieved. There exist published research works indicating that the bacterial degradation of lignin may be more important than previously thought[121]. In addition, there are reports proposing that both fungi (white rot and brown rot fungi) and bacteria (Gram-positive and Gram-negative) can degrade lignin, these papers discussing the metabolic pathways for the degradation of lignin to small phenolic molecules[122-124]. More information about the microbial conversion methods and the different reaction mechanism involved in these treatments are pretty described in some reviews[125].

b. Enzymatic conversion (oxidation): Different enzymatic processes have been applied for lignin depolymerization, most of them involving oxidative processes. The main enzymes that have been studied in lignin degradative processes are lignin peroxidases (LiP) and manganese peroxidase $(\mathrm{MnP})$, which utilize hydrogen peroxide as cofactor for catalyzing oxidation reactions of aromatic rings to radical cations or radical phenoxide group. LiP enzymes may also act in the presence of a mediator such as veratryl alcohol[126]. In the $\mathrm{MnP}$ reaction mechanism, $\mathrm{Mn}(\mathrm{II})$ is oxidized to $\mathrm{Mn}(\mathrm{III})$ and the latter is chelated with an organic acid which acts as a mediator to facilitate the oxidation of phenols whereas other oxidation reactions can also occur in presence of additional compounds, such as thiols or unsaturated lipids. Aromatic rings can also be oxidized to phenoxide-type radicals by enzymes using oxygen $\left(\mathrm{O}_{2}\right)$ as a co-factor, for example Lacassas (Lacc) which also facilitate reactions in the presence of mediators such as hydroxybenzotriazole, among others[127]. It is worth noting that the aromatic alcohols oxidation to produce aldehydes with simultaneous generation of hydrogen peroxide during the process are catalyzed by enzymes like Aryl-AlcoholOxidase (AAO) in combination with aromatic alcohols (i.e. veratryl alcohol, anisyl alcohol), the latter acting as cofactors[127]. As well as for the microbial conversion, excellent reviews summarizing the latest works on the enzymatic treatment of lignin can be encountered[128].

\section{REACTIONS OF LIGNIN DERIVED COMPOUNDS}

Nowadays, lignin is used directly in the formulation of some adhesives of polymeric type, mainly in resins of phenol-formaldehyde (PF) and urea-formaldehyde (UF) type. In addition, modified lignins (i.e. hydroxymethylated lignin) are incorporated into formulations to obtain new adhesives of great industrial interest, including: phenolformaldehyde resins and polymeric diphenylmethane diisocyanate (pMDI). However, these applications are not feasible if the quality of the lignin used and the products obtained are not improved. Current research faces several problems, on the one hand the low purity, the heterogeneity, the smell and the color of the obtained products; and on the other hand, the absence of reliable analytical methods for its characterization. Several authors highlight in their reviews the different applications of lignin in the chemistry of polymers, for example: use as additive or raw material to obtain or to improve the properties of different polymeric products[129-131].

Transformation of compounds derived from lignin presently attracts the attention of researchers, since those compounds play the role as platform chemicals for the synthesis of industrial products, which show various applications (i.e. drugs, dyes, preservatives, polymers, etc.). Polyhydroxylated aromatic compounds (i.e. catechols, quinones, alkylaryl ethers, etc.) are one of the most important classes of compounds used as intermediates or final products in pharmacology, in organic synthesis, and in the electronics industry. In the next paragraphs, some relevant catalytic transformations of lignin derived monomers (i.e. phenols and derivatives, cathecol, guaiacol, vanillin, cinnamyl alcohol, and ferulic acid, among others) to produce interesting high-added value aromatic chemicals will be revised. For a sake of simplicity, the catalytic processes are divided in a) alkylations reactions, and b) other interesting transformations. 
a. Alkylation reactions: The Friedel-Crafts alkylation of phenols with different alcohols including cinnamyl alcohol has been described, by studying the activity of different homogeneous (i.e. $\mathrm{H}_{2} \mathrm{SO}_{4}$ ) and heterogeneous acid catalysts, the latter mainly based on micro-porous silico-aluminates (i.e. HY-zeolites) and mesoporous MCM-41-type materials. The best yields were obtained with the mesoporous catalyst, since due to its morphology the reagents find fewer problems or diffusional restrictions within its pores and channels[132]. H. Garcia et al., have studied in detail the reaction intermediates formed by adsorption of cinnamyl alcohol over zeolites (i.e. H-ZSM-5 and H-MOR), the researchers have confirmed that alkylation proceeds via a reaction mechanism with carbocations formation[133].

Cresols and their derivatives, a family of aromatics compounds widely used in industrial processes, can be obtained by the alkylation of phenol or substituted phenols in gas phase with methanol, and working with different solid catalysts, such as: heteropoly acids supported on silica, zeolites (i.e. H-ZSM-5, H-BEA and HY), and mesoporous materials (i.e. Al-MCM-41). The results show how the pores structure of the catalysts, as well as the nature, density and strength of their acidic sites influence the catalytic activity, selectivity and stability of the materials[134-136].

Bi-phenolic compounds are other interesting aromatic compounds for chemical industry. A new method has been established for the synthesis of bi-phenolic compounds from phenols, the method offers several advantages, including good yields, easy purification, mild reaction conditions and short reaction times (1-2 hours). The synthesis method involves an alkylation reaction between phenols and bis(hydroxymethyl)phenols, mediated by a solid catalyst possessing either Brönsted or Lewis acidity[137].

Catechols type molecules are also attained through lignin depolymerization, these being useful intermediates in organic chemistry. Thus, the guaiacol synthesis by means of ortho-methylation of catechol with methanol has been described using as catalyst sulphated zirconia; the catalyst containing $5 \% \mathrm{wt}$ of $\mathrm{SO}_{4}{ }^{2-}$ groups has reached $80 \%$ conversion and $83 \%$ selectivity to the desired guaiacol by working under moderate reaction conditions (at $200{ }^{\circ} \mathrm{C}$ and 1 bar of pressure). For this process, a reaction mechanism is proposed based on the existence of acid and basic sites (bifunctional catalyst), the acid sites play the role to activate methanol molecules while the basic sites produce a phenolate ion by activating the H-O bond in catechol molecules[138].

Functionalized ionic liquids (i.e. containing sulphonic groups) are emerging as promising catalysts for the alkylation of phenol (and substituted phenols)[113] with tert-butyl alcohol, these catalysts have shown comparable results with some heterogeneous catalysts (i.e. zeolites, acids supported on solids mesoporous, etc.). Thus, phenol conversions of $84.5 \%$ and selectivity referred to 2,4 -ditertbutylphenol of $57.6 \%$ have been reached by working at low temperatures $\left(70{ }^{\circ} \mathrm{C}\right)$. By means of the study of the kinetic model and based on the Arrhenius equation, the value of activation energy was determined as $11.13 \mathrm{kcal} \cdot \mathrm{mol}^{-1}$ for temperatures ranging between $50-90{ }^{\circ} \mathrm{C}[139]$. This reaction has been tested with catechol, obtaining lower conversions than those reported for phenol (32.8\%), while the selectivity to the product 4-tert-butylcatechol does not vary significantly with respect to that of the previous reaction $(61.4 \%)[140]$.

b. Other interesting transformations: Vanillin and ferulic acid are interesting phenolic compounds produced in greater proportion from lignin, both of them can be obtained by oxidative depolymerization of lignin. In the case of vanillin, this aromatic compound is used in the food industry as a flavoring and in the aroma industry, and its annual production is approximately 20,000 tons[141]. For these reasons, many research groups have focused their efforts on the development of efficient processes for the synthesis of this relevant aromatic compound.

Vanillin can be obtained with good results (with 73.5\% conversion and $97.5 \%$ selectivity) through an Oppenauer selective oxidation from hydroxymethyl-guaiacol and aqueous formaldehyde as oxidizing agent, by using a solid acid (Lewis type) Sn-Beta zeolite as catalyst for this process[142]. In a first step, the synthesis of hydroxymethyl-guaiacol by hydroxyalkylation of guaiacol with aqueous formaldehyde is carried out under similar reaction conditions in the presence of Al-containing zeolitetype material as catalyst. Then, in a second step, the selective oxidation is performed in the presence of Sn-Beta zeolite to achieve guaiacol in high yields. In short, several guaiacol derivatives can be used to obtain vanillin, this being a technically and economically viable strategy for the valorization of this type of ligno-derived compounds[143]. Another interesting reaction consists in the asymmetric epoxidation of $\alpha, \beta$-unsaturated alcohols or aldehydes with aromatic ring, such as cinnamyl alcohol, for the preparation of interesting pharmacological compounds. The use of various types of chiral titanium complexes with lactate-type ligands is well known for this type of reactions. The results obtained in terms of activity and enantioselectivity showed a low control of the enantioselectivity by these complexes, probably due to their dynamic behavior[144-145]. Han B. et $a l$. have also studied this reaction by working with a caseinmetal complex (metal: $\mathrm{Fe}, \mathrm{Ni}, \mathrm{Co}, \mathrm{Mn}$, etc.) supported on silica. The best epoxide yields were obtained with the cobalt-based catalyst $(70.6 \%)$ by working at $70{ }^{\circ} \mathrm{C}$ in oxygen atmosphere during 6 hours of reaction[146]. Likewise, triazine-titanium-type complexes immobilized b covalent bonds in a mesoporous solid material (MCM-41) have been prepared and their catalytic activity has been studied in the epoxidation of cinnamyl alcohol. The attained results are comparable to those reported by the aforementioned casein-Co catalyst, but using longer reaction times[147].

These are just few selected examples of the plentiful catalytic processes available to transform aromatic lignin derivatives into valuable chemical compounds for industry.

\section{RESUME AND FUTURE PERSPECTIVES.}

This tutorial review explored the potential of lignin to become a source of important platform chemicals that can replace those synthesized from fossil carbon feedstock. Methods for extraction and isolation of lignin-derived 
monomers were explored, mainly focusing on the most promising degradative and non-degradative processing strategies, which are currently utilized to extract or depolymerize the lignin portion of biomass into useful aromatic chemical compounds. In this context, four different methods to perform the depolymerization of lignin were shown, where their selectivity depends on many factors associated to each method, such as type of lignin, reagents used, pressure or temperature. In general, the most effective methods to depolymerize lignin with high efficiency and selectivity are those using catalysts, mainly due to fact that they work under milder reaction conditions, thus making more sustainable the whole process. Some strategies for the efficient catalytic transformations of these lignin-derived monomers (model compounds) has been also discussed, indicating a new wave of source of aromatic chemicals. Development of innovative strategies including both the methods for extraction and isolation of lignin derivatives and their efficient conversion into high-added value aromatic chemicals will open new routes to turn away from fossil carbon feedstocks commonly used in chemical industry, thus replacing them with non-edible biomass sources.

\section{ACKNOWLEDGEMENTS}

Financial support by Spanish Government (CTQ-201567592, CTQ2016-81848-REDT, and SEV-2016-0683) and by PhosAgro/UNESCO/IUPAC Partnership (Proj. 139) is gratefully acknowledged. M.C-S. thanks ITQ for this postdoctoral stay support.

\section{REFERENCES}

[1] Hara, M.; Nakajima, K.; Kamata, K. Recent progress in the development of solid catalysts for biomass conversion into high value-added chemicals. Sci. Tech. Adv. Mater. 2015, 16(3), 1-22.

[2] Esposito, D.; Antonietti, M. Redefining biorefinery: the search for unconventional building blocks for materials. Chem. Soc. Rev. 2015, 44(16), 5821-5835.

[3] Bar-On, Y. M.; Phillips, R.; Milo, R., The biomass distribution on Earth. PNAS 2018, 115(25), 6506-6511. [4] Hughes, S. R.; Qureshi, N. Chapter 2 - Biomass for Biorefining: Resources, Allocation, Utilization, and Policies. In Biorefineries, Qureshi, N.; Hodge, D. B.; Vertès, A. A., Eds. Elsevier: Amsterdam, 2014; pp 37-58. [5] Wang, Y.-Y.; Cai, C. M.; Ragauskas, A. J. Recent advances in lignin-based polyurethanes. Tappi J. 2017, 16(4), 203-207.

[6] Hicks, J. C. Advances in C-O Bond Transformations in Lignin-Derived Compounds for Biofuels Production. $J$.

Phys. Chem. Lett. 2011, 2(18), 2280-2287.

[7] Sudarsanam, P.; Zhong, R.; Van den Bosch, S.; Coman, S. M.; Parvulescu, V. I.; Sels, B. F. Functionalised heterogeneous catalysts for sustainable biomass valorisation. Chem. Soc. Rev. 2018, 47(22), 8349-8402. [8] Guo, T.; Li, X.; Liu, X.; Guo, Y.; Wang, Y. Catalytic Transformation of Lignocellulosic Biomass into Arenes, 5Hydroxymethylfurfural, and Furfural. ChemSusChem 2018, 11(16), 2758-2765.
[9] Den, W.; Sharma, V. K.; Lee, M.; Nadadur, G.; Varma, R. S. Lignocellulosic Biomass Transformations via Greener Oxidative Pretreatment Processes: Access to Energy and Value-Added Chemicals. Front. Chem. 2018, 6(141), 1-23. [10] Gargulak, J. D.; Lebo, S. E. Commercial Use of Lignin-Based Materials. In Lignin: Historical, Biological, and Materials Perspectives, American Chemical Society: 1999; Vol. 742, pp 304-320.

[11] Insights, G. M. Global Lignin Market worth; Selbyville, Delaware 19975 USA, 2018.

[12] Lu, F.; Ralph, J. Chapter 6 - Lignin. In Cereal Straw as a Resource for Sustainable Biomaterials and Biofuels, Sun, R.-C., Ed. Elsevier: Amsterdam, 2010; pp 169-207.

[13] Saha, K.; Dwibedi, P.; Ghosh, A.; Sikder, J.; Chakraborty, S.; Curcio, S. Extraction of lignin, structural characterization and bioconversion of sugarcane bagasse after ionic liquid assisted pretreatment. 3 Biotech 2018, 8, 374. https://doi.org/10.1007/s13205-018-1399-4.

[14] Gellerstedt, G.; Li, J.; Eide, I.; Kleinert, M.; Barth, T. Chemical structures present in biofuel obtained from lignin. Energy Fuels 2008, 22, 4240-4244.

[15] Gellerstedt, G.; Henriksson, G. Lignins: Major sources, structure and properties. In Monomers, Polymers and Composites from Renewable Resources, Naceur Belgacem, M.; Gandini, A., Eds. Elsevier B.V.: Amsterdam, 2008; pp 201-224.

[16] B. Davin, L.; G. Lewis, N. Lignin primary structures as dirigents sites. Curr Opin Biotechnol 2005, 16, 407-415.

[17] Fernández-Rodríguez, J.; Erdocia, X.; Sánchez, C.; González Alriols, M.; Labidi, J. Lignin depolymerization for phenolic monomers production by sustainable processes. J. Energ. Chem. 2017, 26(4), 622-631.

[18] Ahuja, D.; Kaushik, A.; Singh, M. Simultaneous extraction of lignin and cellulose nanofibrils from waste jute bags using one pot pre-treatment. Int. J. Biol. Macromolec. 2018, 107, 1294-1301.

[19] Strassberger, Z.; Prinsen, P.; Klis, F. v. d.; Es, D. S. v.; Tanase, S.; Rothenberg, G. Lignin solubilisation and gentle fractionation in liquid ammonia. Green Chem. 2015, 17(1), 325-334.

[20] Bi, Z.; Lai, B.; Zhao, Y.; Yan, L. Fast Disassembly of Lignocellulosic Biomass to Lignin and Sugars by Molten Salt Hydrate at Low Temperature for Overall Biorefinery. ACS Omega 2018, 3(3), 2984-2993.

[21] Obst, J.; Kirk, K. Isolation of lignin. In Methods in enzymology, Willis A., W.; Scott T., K., Eds. Academic Press, Inc.: San Diego CA, 1988; Vol. 161, pp 3-12. [22] Han, T.; Sophonrat, N.; Evangelopoulos, P.; Persson, H.; Yang, W.; Jönsson, P. Evolution of sulfur during fast pyrolysis of sulfonated Kraft lignin. J. Anal. Appl. Pyr. 2018, 133, 162-168.

[23] Beňo, E.; Góra, R.; Hutta, M. Characterization of Klason lignin samples isolated from beech and aspen using microbore column size-exclusion chromatography. J. Sep. Sci. 2018, 41(16), 3195-3203.

[24] Bunzel, M.; Schüßler, A.; Tchetseubu Saha, G. Chemical Characterization of Klason Lignin Preparations from Plant-Based Foods. J. Agric. Food Chem. 2011, 59, 12506-12513.

[25] El Mansouri, N.-E.; Yuan, Q.; Huang, F.

Characterization of alkaline lignins for use in phenol- 
formaldehyde and epoxy resins. BioRes. 2011, 6(3), 26472662.

[26] Hita, I.; Deuss, P. J.; Bonura, G.; Frusteri, F.; Heeres, H. J. Biobased chemicals from the catalytic depolymerization of Kraft lignin using supported noble metal-based catalysts. Fuel Proc. Tech. 2018, 179, 143-153. [27] Chakar, F. S.; Ragauskas, A. J. Review of Current and Future Softwood Kraft Lignin Process Chemistry. Ind. Crops Prod. 2004, 20, 131-141.

[28] Moutsoglou, A.; Lawburgh, B.; Lawburgh, J. Fractional condensation and aging of pyrolysis oil from softwood and organosolv lignin. J. Anal. Appl. Pyr. 2018, 135, 350-360.

[29] Dou, J.; Kim, H.; Li, Y.; Padmakshan, D.; Yue, F.; Ralph, J.; Vuorinen, T. Structural Characterization of Lignins from Willow Bark and Wood. J. Agric. Food Chem. 2018, 66(28), 7294-7300.

[30] Guerra, A.; Filpponen, I.; Lucia, L. A.; Argyropoulos, D. S. Comparative Evaluation of Three Lignin Isolation Protocols for Various Wood Species. J. Agric. Food Chem. 2006, 54, 9696-9705.

[31] You, T.; Wang, R.; Zhang, X.; Ramaswamy, S.; Xu, F. Reconstruction of lignin and hemicelluloses by aqueous ethanol anti-solvents to improve the ionic liquid-acid pretreatment performance of Arundo donax Linn. Biotech. Bioeng. 2017, 115(1), 82-91.

[32] Hart, W. E. S.; Aldous, L.; Harper, J. B. Nucleophilic Cleavage of Lignin Model Compounds under Acidic Conditions in an Ionic Liquid: A Mechanistic Study. ChemPlusChem 2018, 83(5), 348-353.

[33] Hu, J.; Zhang, Q.; Lee, D.-J. Kraft lignin biorefinery: A perspective. Biores. Tech. 2018, 247, 1181-1183.

[34] Lora, J. Industrial comercial lingins: Sources, properties and applications. In Monomers, Polymers and Composites from Renewable Resources. Naceur Belgacem, M.; Gandini, A., Eds. Elsevier B.V.: Amsterdam, 2008; pp 225-241.

[35] Vishtal, A.; Kraslawski, A. Challenges in industrial applications of technical lignins. BioResources 2011, 6 , 3547-3568.

[36] Ghorbani, M.; Konnerth, J.; van Herwijnen, H. W. G.; Zinovyev, G.; Budjav, E.; Requejo Silva, A.; Liebner, F. Commercial lignosulfonates from different sulfite processes as partial phenol replacement in PF resole resins. J. Appl. Pol. Sci. 2018, 135(8), 45893.

[37] Huang, S.; Mahmood, N.; Zhang, Y.; Tymchyshyn, M.; Yuan, Z.; Xu, C. Reductive depolymerization of kraft lignin with formic acid at low temperatures using inexpensive supported Ni-based catalysts. Fuel 2017, 209, 579-586.

[38] Fang, H.; Li, C.; Qian, C.; Cui, P.; Yang, Y.; Liu, T. Separation process of mild acid-catalyzed lignin depolymerization product and extracted product thereof. CN Patent 106366134A, August 8, 2017.

[39] Aro, T.; Fatehi, P. Production and Application of Lignosulfonates and Sulfonated Lignin. ChemSusChem 2017, 10(9), 1861-1877.

[40] Gupta, A.; Gupta, R. Treatment and Recycling of Wastewater from Pulp and Paper Mill. In Advances in Biological Treatment of Industrial Waste Water and their
Recycling for a Sustainable Future. Singh, R. L.; Singh, R. P., Eds. Springer Singapore: Singapore, 2019; pp 13-49.

[41] Wang, G.; Chen, H. Fractionation of alkali-extracted lignin from steam-exploded stalk by gradient acid precipitation. Sep. Purif. Tech. 2013, 105, 98-105. [42] Liu, G.; Liu, Y.; Ni, J.; Shi, H.; Qian, Y. Treatability of kraft spent liquor by microfiltration and ultrafiltration. Desalination 2004, 160(2), 131-141.

[43] Ooi, Z.-Y.; Harruddin, N.; Othman, N. Recovery of kraft lignin from pulping wastewater via emulsion liquid membrane process. Biotech Progress 2015, 31(5), 13051314.

[44] Ferrer, A.; Byers, F. M.; Sulbarán-de-Ferrer, B.; Dale, B. E.; Aiello, C. Optimizing Ammonia

Pressurization/Depressurization Processing Conditions to Enhance Enzymatic Susceptibility of Dwarf Elephant Grass. In Twenty-First Symposium on Biotechnology for Fuels and Chemicals: Proceedings of the Twenty-First Symposium on Biotechnology for Fuels and Chemicals Held May 2-6, 1999, in Fort Collins, Colorado, Finkelstein, M.; Davison, B. H., Eds. Humana Press: Totowa, NJ, 2000; pp 163-179. [45] Yoo, C. G.; Nghiem, N. P.; Hicks, K. B.; Kim, T. H. Pretreatment of corn stover using low-moisture anhydrous ammonia (LMAA) process. Biores. Tech. 2011, 102(21), 10028-10034.

[46] Serrano, L.; Spigno, G.; García, A.; Amendola, D.; Labidi, J. Properties of Soda and Organosolv Lignins from Apple Tree Pruning. J. Biobased Mater. Bioenergy 2012, 6(3), 329-335.

[47] Kim, J. S.; Lee, Y. Y.; Kim, T. H. A review on alkaline pretreatment technology for bioconversion of lignocellulosic biomass. Biores. Tech. 2016, 199, 42-48. [48] Wu, L.; Arakane, M.; Ike, M.; Wada, M.; Takai, T.; Gau, M.; Tokuyasu, K. Low temperature alkali pretreatment for improving enzymatic digestibility of sweet sorghum bagasse for ethanol production. Biores. Tech. 2011, 102(7), 4793-4799.

[49] Kim, T. H.; Kim, J. S.; Sunwoo, C.; Lee, Y. Y. Pretreatment of corn stover by aqueous ammonia. Biores. Tech. 2003, 90(1), 39-47.

[50] Kim, T. H.; Gupta, R.; Lee, Y. Y. Pretreatment of Biomass by Aqueous Ammonia for Bioethanol Production. In Biofuels: Methods and Protocols, Mielenz, J. R., Ed. Humana Press: Totowa, NJ, 2009; pp 79-91.

[51] Rodríguez, A.; Moral, A.; Sánchez, R.; Jiménez, L. Use of diethanolamine to obain cellulosics pulps from solid fraction of hydrothermal treatment of rice straw. Afinidad 2009, 65(539), 20-26.

[52] Lu, F.; John, R. Lignin. In Cereal Straw as a Resource for Sustainable Biochemicals and Biofuels. Elsevier B.V.: Amsterdam, 2010; pp 169-207.

[53] de la Torre, M. J.; Moral, A.; Hernández, M. D.; Cabeza, E.; Tijero, A. Organosolv lignin for biofuel. Ind. Crops Prod. 2013, 45, 58-63.

[54] Vishtal, A.; Kraslawski, A. Challenges in industrial applications of technical lignins. BioRes. 2011, 6, 35473568.

[55] Mohamad Ibrahim, M. N.; Sripransathi, R. B.; Shamsudeen, S.; Adam, F.; Bhawani, S. A concise review of the natural existance synthesis, properties and applications of syringaldehyde. BioRes. 2012, 7, 1-23. 
[56] García Calvo-Flores, F.; Dobado, J. A. Lignin as renewable raw material. Chem. Sust. Ener. Mat. 2010, 3, 1227-1235.

[57] Lora, J. H.; Glasser, W. G. Recent industrial applications of lignin: A sustainable alternative to nonrenewable materials. J. Pol. Environ. 2002, 10, 39-48. [58] Gandini, A.; Naceur Belgacem, M. Lignins as components of macromolecular materials. In Monomers, Polymers and Composites from Renewable Resources. Naceur Belgacen, M.; Gandini, A., Eds. Elsevier B.V.: Amsterdam, 2008; pp 243-270.

[59] Holladay, J. E.; Bozell, J. J.; White, J. F.; Johnson, D. J. Top Value-Added Chemicals from Biomass-Volumen II: Results of screening for potential candidates from biorefinery lignin; U.S. Department of Energy: United States of America, 2007.

[60] Ma, R.; Xu, Y.; Zhang, X. Catalytic Oxidation of Biorefinery Lignin to Value-added Chemicals to Support Sustainable Biofuel Production. ChemSusChem 2015, 8(1), 24-51.

[61] Sedai, B.; Díaz-Urrutia, C.; Baker, R. T.; Wu, R.; Silks, L. A. P.; Hanson, S. K. Comparison of Copper and Vanadium Homogeneous Catalysts for Aerobic Oxidation of Lignin Models. ACS Catal. 2011, 1(7), 794-804. [62] Li, J.; Henriksson, G.; Gellerstedt, G. Lignin depolymerization/repolymerization and its critical role for delignification of aspen wood by steam explosion. Biores. Tech. 2007, 98(16), 3061-3068.

[63] Deng, H.; Lin, L.; Sun, Y.; Pang, C.; Zhuang, J.; Ouyang, P.; Li, J.; Liu, S. Activity and Stability of Perovskite-Type Oxide $\mathrm{LaCoO}_{3}$ Catalyst in Lignin Catalytic Wet Oxidation to Aromatic Aldehydes Process. Energy Fuels 2009, 23(1), 19-24.

[64] Deng, H.; Lin, L.; Liu, S. Catalysis of Cu-Doped CoBased Perovskite-Type Oxide in Wet Oxidation of Lignin To Produce Aromatic Aldehydes. Energy Fuels 2010, 24(9), 4797-4802.

[65] Gu, X.; Kanghua, C.; Ming, H.; Shi, Y.; Li, Z. Lamodified SBA- $15 / \mathrm{H}_{2} \mathrm{O}_{2}$ systems for the microwave assisted oxidation of organosolv beech wood lignin. Maderas.

Cienc. Tecnol. 2012, 14, 31-41.

[66] Tavares, A. P. M.; Gamelas, J. A. F.; Gaspar, A. R.; Evtuguin, D. V.; Xavier, A. M. R. B. A novel approach for the oxidative catalysis employing polyoxometalate-laccase system: application to the oxygen bleaching of kraft pulp. Catal. Comm. 2004, 5(9), 485-489.

[67] Gamelas, J. A. F.; Gaspar, A. R.; Evtuguin, D. V.; Pascoal Neto, C. Transition metal substituted polyoxotungstates for the oxygen delignification of kraft pulp. Appl. Catal. A: Gen. 2005, 295(2), 134-141. [68] Hdidou, L.; Khallouk, K.; Solhy, A.; Manoun, B.; Oukarroum, A.; Barakat, A. Synthesis of $\mathrm{CoFeO}$ mixed oxides via an alginate gelation process as efficient heterogeneous catalysts for lignin depolymerization in water. Catal. Sci. Tech. 2018, 8, 5445-5453.

[69] Mottweiler, J.; Puche, M.; Räuber, C.; Schmidt, T.; Concepción, P.; Corma, A.; Bolm, C. Copper- and Vanadium-Catalyzed Oxidative Cleavage of Lignin using Dioxygen. ChemSusChem 2015, 8(12), 2106-2113.

[70] Kruger, J. S.; Cleveland, N. S.; Zhang, S.; Katahira, R.; Black, B. A.; Chupka, G. M.; Lammens, T.; Hamilton, P.
G.; Biddy, M. J.; Beckham, G. T. Lignin Depolymerization with Nitrate-Intercalated Hydrotalcite Catalysts. ACS Catal. 2016, 6(2), 1316-1328.

[71] Li, C.; Zhao, X.; Wang, A.; Huber, G. W.; Zhang, T. Catalytic Transformation of Lignin for the Production of Chemicals and Fuels. Chem. Rev. 2015, 115(21), 1155911624 .

[72] Zakzeski, J.; Bruijnincx, P. C. A.; Jongerius, A. L.; Weckhuysen, B. M. The Catalytic Valorization of Lignin for the Production of Renewable Chemicals. Chem. Rev. 2010, 110(6), 3552-3599.

[73] Yan, N.; Zhao, C.; Dyson, P. J.; Wang, C.; Liu, L.-T.; Kou, Y. Selective degradation of wood lignin over noblemetal catalysis in a two-step process. ChemSusChem 2008, 1, 626-629.

[74] Yu, J.; Savage, P. E. Decomposition of formic acid under hydrothermal conditions. Ind. Eng. Chem. Res. 1998, 37, 2-10.

[75] Macala, G. S.; Matson, T. D.; Johnson, C. L.; Lewis, R. S.; Iretskii, A. V.; Ford, P. C. Hydrogen transfer from supercritical methanol over a solid base catalyst: A model for lignin depolymerization. ChemSusChem 2009, 2, 215217.

[76] Gosselink, R. J. A.; Teunissen, W.; van Dam, J. E. G.; de Jong, E.; Gellerstedt, G.; Scott, E. L.; Sanders, J. P. M. Lignin depolymerisation in supercritical carbon dioxide/acetone/water fluid for the production of aromatic chemicals. Biores. Tech. 2012, 106, 173-177.

[77] Barta, K.; Matson, T. D.; Fettig, M. L.; Scott, S. L.; Iretskii, A. V.; Ford, P. C. Catalytic disassembly of an organosolv lignin via hydrogen transfer from supercritical methanol. Green Chem. 2010, 12, 1640-1647.

[78] Shabtai, J. S.; Zmierczak, W. W. Process for conversion of lignin to reformulated hydrocarbon gasoline. US Patent 5,959,167 A, September 28, 1999.

[79] Shabtai, J. S.; Zmierczak, W. W. Process for conversion of lignin to reformulated, partially oxygenated gasoline. US Patent 6,172,272 B1, 2001.

[80] Stone, M. L.; Anderson, E. M.; Meek, K. M.; Reed, M.; Katahira, R.; Chen, F.; Dixon, R. A.; Beckham, G. T.; Román-Leshkov, Y. Reductive Catalytic Fractionation of CLignin. ACS Sus. Chem. Engin. 2018, 6(9), 11211-11218. [81] Chen, J. Z.; Lu, F.; Si, X. Q.; Nie, X.; Chen, J. S.; Lu, R.; Xu, J. High Yield Production of Natural Phenolic Alcohols from Woody Biomass Using a Nickel-Based Catalyst. Chemsuschem 2016, 9(23), 3353-3360.

[82] Domine, M. E.; Chávez-Sifontes, M.; Gutierrez, A.; Vilonen, K.; Strengell, T.; Jokela, P.; Eilos, I. Simple Process for Converting Lignocellulosic Materials. WO Patent 2018/015610 A1, January 25, 2018.

[83] Domine, M. E.; Chávez-Sifontes, M.; Gutierrez, A.; Vilonen, K.; Strengell, T.; Jokela, P.; Eilos, I. Process for Converting Lignocellulosic Materials. WO Patent 2018/015608 A1, January 25, 2018.

[84] Domine, M. E.; Chávez-Sifontes, M.; Gutierrez, A. Catalyst Composition. WO Patent 2018/015609 A1, January 25, 2018.

[85] Renders, T.; Cooreman, E.; Van den Bosch, S.; Schutyser, W.; Koelewijn, S. F.; Vangeel, T.; Deneyer, A.; Van den Bossche, G.; Courtin, C. M.; Sels, B. F. Catalytic lignocellulose biorefining in n-butanol/water: a one-pot 
approach toward phenolics, polyols, and cellulose. Green Chem. 2018, 20(20), 4607-4619.

[86] Tekin, K.; Hao, N.; Karagoz, S.; Ragauskas, A. J. Ethanol: A Promising Green Solvent for the Deconstruction of Lignocellulose. ChemSusChem 2018, 11(20), 3559-3575. [87] Limarta, S. O.; Ha, J.-M.; Park, Y.-K.; Lee, H.; Suh, D. J.; Jae, J. Efficient depolymerization of lignin in supercritical ethanol by a combination of metal and base catalysts. J. Ind. Eng. Chem. 2018, 57, 45-54.

[88] Kuznetsov, B. N.; Sharypov, V. I.; Chesnokov, N. V.; Beregovtsova, N. G.; Baryshnikov, S. V.; Lavrenov, A. V.; Vosmerikov, A. V.; Agabekov, V. E. Lignin conversion in supercritical ethanol in the presence of solid acid catalysts. Kinet. Catal. 2015, 56(4), 434-441.

[89] Cao, L.; Zhang, C.; Chen, H.; Tsang, D. C. W.; Luo, G.; Zhang, S.; Chen, J. Hydrothermal liquefaction of agricultural and forestry wastes: state-of-the-art review and future prospects. Biores. Tech. 2017, 245, 1184-1193. [90] Chandrasekaran, S. R.; Murali, D.; Marley, K. A.; Larson, R. A.; Doll, K. M.; Moser, B. R.; Scott, J.; Sharma, B. K. Antioxidants from Slow Pyrolysis Bio-Oil of Birch Wood: Application for Biodiesel and Biobased Lubricants. ACS Sus. Chem. Eng. 2016, 4(3), 1414-1421.

[91] Kang, S.; Li, X.; Fan, J.; Chang, J. Hydrothermal conversion of lignin: A review. Renew. Sus. Energ. Rev. 2013, 27, 546-558.

[92] Joffres, B.; Lorentz, C.; Vidalie, M.; Laurenti, D.; Quoineaud, A. A.; Charon, N.; Daudin, A.; Quignard, A.; Geantet, C. Catalytic hydroconversion of a wheat straw soda lignin: Characterization of the products and the lignin residue. Appl. Catal B: Environ. 2014, 145, 167-176. [93] Zhang, B.; Huang, H.-J.; Ramaswamy, S. Reaction Kinetics of the Hydrothermal Treatment of Lignin. Appl. Biochem. Biotech. 2008, 147(1), 119-131.

[94] Tymchyshyn, M.; Xu, C. Liquefaction of bio-mass in hot-compressed water for the production of phenolic compounds. Biores. Tech. 2010, 101(7), 2483-2490. [95] Schuler, J.; Hornung, U.; Kruse, A.; Dahmen, N.; Sauer, J. Hydrothermal Liquefaction of Lignin. J. Biomat. Nanobiotech. 2017, 8(1), 13.

[96] Yoshida, K.; Kusaki, J.; Ehara, K.; Saka, S. Characterization of Low Molecular Weight Organic Acids from Beech Wood Treated in Supercritical Water. In Twenty-Sixth Symposium on Biotechnology for Fuels and Chemicals, Davison, B. H.; Evans, B. R.; Finkelstein, M.; McMillan, J. D., Eds. Humana Press: Totowa, NJ, 2005; pp 795-806.

[97] Rahimi, A.; Ulbrich, A.; Coon, J. J.; Stahl, S. S. Formic-acid-induced depolymerization of oxidized lignin to aromatics. Nature 2014, 515, 249.

[98] Shuai, L.; Amiri, M. T.; Questell-Santiago, Y. M.; Héroguel, F.; Li, Y.; Kim, H.; Meilan, R.; Chapple, C.; Ralph, J.; Luterbacher, J. S. Formaldehyde stabilization facilitates lignin monomer production during biomass depolymerization. Science 2016, 354(6310), 329-333. [99] Cao, L.; Zhang, C.; Chen, H.; Tsang, D. C. W.; Luo, G.; Zhang, S.; Chen, J. Hydrothermal liquefaction of agricultural and forestry wastes: state-of-the-art review and future prospects. Biores.Tech. 2017, 245, 1184-1193.
[100] Drage, T. C.; Vane, C. H.; Abbott, G. D. The closed system pyrolysis of $\beta$-O-4 lignin substructure model compounds. Org. Geochem. 2002, 33(12), 1523-1531. [101] Tudorache, M.; Opris, C.; Cojocaru, B.; Apostol, N. G.; Tirsoaga, A.; Coman, S. M.; Parvulescu, V. I.; Duraki, B.; Krumeich, F.; van Bokhoven, J. A. Highly Efficient, Easily Recoverable, and Recyclable $\mathrm{Re}-\mathrm{SiO}_{2}-\mathrm{Fe}_{3} \mathrm{O}_{4}$ Catalyst for the Fragmentation of Lignin. ACS Sus. Chem. Engin. 2018, 6(8), 9606-9618.

[102] Ma, Z.; Ghosh, A.; Asthana, N.; van Bokhoven, J. Visualization of Structural Changes During Deactivation and Regeneration of FAU Zeolite for Catalytic Fast Pyrolysis of Lignin Using NMR and Electron Microscopy Techniques. ChemCatChem 2018, 10(19), 4431-4437. [103] Thring, R. W.; Katikaneni, S. P. R.; Bakhshi, N. N. The production of gasoline range hydrocarbons from Alcell lignin using HZSM-5 catalyst. Fuel Processing Technology 2000, 62, 17-30.

[104] Amen-Chen, C.; Pakdel, H.; Roy, C. Production of monomeric phenols by thermochemical conversion of biomass: a review. Biores. Tech. 2001, 79(3), 277-299. [105] Collard, F.-X.; Blin, J. A review on pyrolysis of biomass constituents: Mechanisms and composition of the products obtained from the conversion of cellulose, hemicelluloses and lignin. Renew. Sus. Energ. Rev. 2014, 38, 594-608.

[106] Bu, Q.; Lei, H.; Zacher, A. H.; Wang, L.; Ren, S.; Liang, J.; Wei, Y.; Liu, Y.; Tang, J.; Zhang, Q.; Ruan, R. A review of catalytic hydrodeoxygenation of lignin-derived phenols from biomass pyrolysis. Biores. Tech. 2012, 124, 470-477.

[107] Liguori, L.; Barth, T. Palladium-Nafion SAC 13 catalyses depolymerisation of lignin to phenols in formic acid and water. J. Anal. Appl. Pyr. 2011, 92, 477-484.

[108] Hepditch, M. M.; Thring, R. Degradation of solvolysis lignin using Lewis acid catalysts. Can. J. Chem. Eng. 2000, 78, 226-231.

[109] Binder, J. B.; Gray, M. J.; White, J. F.; Conrad Zhang, Z.; Holladay, J. E. Reactions of lignin model compounds in ionic liquids. Biomass and Bioenergy 2009, 33, 1122-1130. [110] Prado, R.; Erdocia, X.; Labidi, J. Lignin extraction and purification with ionic liquids. J. Chem. Tech. Biotech. 2013, 88(7), 1248-1257.

[111] Dier, T. K. F.; Rauber, D.; Durneata, D.; Hempelmann, R.; Volmer, D. A. Sustainable Electrochemical Depolymerization of Lignin in Reusable Ionic Liquids. Sci Rep. 2017, 7(1), 5041

(DOI:10.1038/s41598-017-05316-x).

[112] Wang, H.; Tucker, M.; Ji, Y. Recent Development in Chemical Depolymerization of Lignin: A Review. J. Appl. Chem. 2013, 2013, 1-9.

http://dx.doi.org/10.1155/2013/838645.

[113] Mora-Pale, M.; Meli, L.; Doherty, T. V.; Linhardt, R. J.; Dordick, J. S. Room temperature ionic liquids as emerging solvents for the pretreatment of lignocellulosic biomass. Biotech. Bioeng. 2011, 108(6), 1229-1245. [114] Lavoie, J.-M.; Baré, W.; Bilodeau, M.

Depolymerization of steam-treated lignin for the production of green chemicals. Biores. Tech. 2011, 102(7), 4917-4920. [115] Dabral, S.; Engel, J.; Mottweiler, J.; Spoehrle, S. S. M.; Lahive, C. W.; Bolm, C. Mechanistic studies of base- 
catalysed lignin depolymerisation in dimethyl carbonate. Green Chem. 2018, 20(1), 170-182.

[116] Roberts, V. M.; Stein, V.; Reiner, T.; Lemonidou, A.; Li, X.; Lercher, J. A. Towards Quantitative Catalytic Lignin Depolymerization. Chem. Eur. J. 2011, 17(21), 5939-5948.

[117] Toledano, A.; Serrano, L.; Labidi, J. Organosolv lignin depolymerization with different base catalysis. $J$. Chem. Tech. Biotech. 2012, 87, 1593-1599.

[118] Nenkova, S.; Vasileva, T.; Stanulov, K. Production of phenol compounds by alkaline treatment of technical hydrolysis lignin and wood biomass. Chemistry of Natural Compounds 2008, 44, 182-185.

[119] Roberts, V. M.; Stein, V.; Reiner, T.; Lemonidou, A.; Li, X.; Lercher, J. A. Towards quantitative catalytic lignin depolymerization. Chem. Eur. J. 2011, 17, 5939-5948. [120] Beauchet, R.; Monteil-Rivera, F.; Lavoie, J. M. Conversion of lignin to aromatic-based chemicals (Lchems) and biofuels (L-fuels). Biores. Tech. 2012, 121, 328-334.

[121] Bugg, T. D. H.; Ahmad, M.; Hardiman, E. M.; Rahmanpour, R. Pathways for degradation of lignin in bacteria and fungi. Nat. Prod. Rep. 2011, 28(12), 18831896.

[122] Higuhi, T. Microbial degradation of lignin: Role of lignin peroxidase, manganese peroxidase and laccase. Procceedings of Japan Academy, Ser. B. Physical and Biological Sciences 2004, 80, 204-214.

[123] D. H. Bugg, T.; Ahmad, M.; M Hardiman, E.; Singh, $\mathrm{R}$. The emerging role for bacteria in lignin degradation and bio-product formation. Curr. Opin. Biotechnol. 2011, 22, 394-400.

[124] D.H. Bugg, T.; Ahmad, M.; Hardiman, E. M.; Rahmanpour, R. Pathways for degradation of lignin in bacteria and fungi. Natural Products Report 2011, 28, 1883-1896.

[125] Janusz, G.; Pawlik, A.; Sulej, J.; Swiderska-Burek, U.; Jarosz-Wilkolazka, A.; Paszczynski, A. Lignin degradation: microorganisms, enzymes involved, genomes analysis and evolution. FEMS microbiol. Rev. 2017, 41(6), 941-962.

[126] Goodwin, D. C.; Aust, S. D.; Grover, T. A. Evidence for Veratryl Alcohol as a Redox Mediator in Lignin Peroxidase-Catalyzed Oxidation. Biochemistry 1995, 34(15), 5060-5065.

[127] Hatakka, A. Biodegradation of lignin. In Biopolymers-Lignin, Humic Substances and Coal, Hofrichter, M.; Steinbüchel, A., Eds. Wiley-VCH: 2004; Vol. 1, pp 129-145.

[128] Pollegioni, L.; Tonin, F.; Rosini, E. Lignin-degrading enzymes. The FEBS Journal 2015, 282(7), 1190-1213. [129] Zhang, X.; Tang, W.; Zhang, Q.; Wang, T.; Ma, L. Hydrocarbons Production from Lignin-derived Phenolic Compounds over Ni/SiO 2 Catalyst. Energ. Proc. 2017, 105, 518-523.

[130] Upton, B. M.; Kasko, A. M. Strategies for the Conversion of Lignin to High-Value Polymeric Materials: Review and Perspective. Chem. Rev. 2016, 116(4), 22752306.

[131] Rueping, M.; Nachtsheim, B. J. A review of new developments in the Friedel-Crafts alkylation - From green chemistry to asymmetric catalysis. Beilstein J. Org. Chem. 2010, 6, 6-6.

[132] Adam, W.; Casades, I.; Fornés, V.; García, H.; Weichold, O. UV-vis and IR Spectral Characterization of Persistent Carbenium Ions, Generated upon Incorporation of Cinnamyl Alcohols in the Acid Zeolites HZSM-5 and HMor. J. Org. Chem. 2000, 65(13), 3947-3951.

[133] Sad, M. E.; Padró, C. L.; Apesteguía, C. R. Synthesis of cresols by alkylation of phenol with methanol on solid acids. Catal. Today 2008, 133-135, 720-728.

[134] Yoshikawa, T.; Umezawa, T.; Nakasaka, Y.; Masuda, T. Conversion of alkylphenol to phenol via transalkylation using zeolite catalysts. Catal. Today 2018, Ahead of Print. [135] Liao, Y.; d'Halluin, M.; Makshina, E.; Verboekend, D.; Sels, B. F. Shape selectivity vapor-phase conversion of lignin-derived 4-ethylphenol to phenol and ethylene over acidic aluminosilicates: Impact of acid properties and pore constraint. Appl. Catal. B: Environ. 2018, 234, 117-129. [136] Vishwanathan, V.; Balakrishna, G.; Rajesh, B.; Jayasri, V.; Sikhwivhilu, L. M.; Coville, N. J. Alkylation of catechol with methanol to give guaiacol over sulphatemodified zirconia solid acid catalysts: The influence of structural modification of zirconia on catalytic performance. Catal. Commun. 2008, 9(14), 2422-2427.

[137] Fache, M.; Boutevin, B.; Caillol, S. Vanillin Production from Lignin and Its Use as a Renewable Chemical. ACS Sus. Chem. Eng. 2016, 4(1), 35-46. [138] Franco, A.; De, S.; Balu, A. M.; Romero, A. A.; Luque, R. Selective Oxidation of Isoeugenol to Vanillin over Mechanochemically Synthesized Aluminosilicate Supported Transition Metal Catalysts. ChemistrySelect 2017, 2(29), 9546-9551.

[139] Nie, X.; Liu, X.; Gao, L.; Liu, M.; Song, C.; Guo, X. $\mathrm{SO}_{3} \mathrm{H}$-Functionalized Ionic Liquid Catalyzed Alkylation of Catechol with tert-Butyl Alcohol. Ind. Eng. Chem. Res. 2010, 49(17), 8157-8163.

[140] Njiojob Ngnouomeuchi, C.; Bulino, C.; Bozell, J. J.; Long, B. K. In Synthesis of enantiomerically pure lignin dimers for catalytic degradation using organometallic catalysts, American Chemical Society: 2014; pp ORGN-95. [141] Zhao, F. E. A. Method for preparing Vanillin. WO Patent 2003/064363 A1, 2016.

[142] Jacquot, R.; Corma, A.; Domine, M. Process of preparation of an aromatic aldehyde, e.g. vanillin, by oxidation of aromatic hydroxymethyl compounds with formaldehyde using $\beta$-type zeolites containing tin, titanium, and/or aluminium. FR Patent 2835251, 2002.

[143] Oregui-Bengoechea, M.; Gandarias, I.; Arias, P. L.; Barth, T. Solvent and catalyst effect in the formic acid aided lignin-to-liquids. Bioresour. Technol. 2018, 270, 529-536. [144] Pérez, Y.; del Hierro, I.; Fajardo, M. Synthesis of titanium alkoxide complexes with alkyl lactate ligands. Asymmetric epoxidation of cinnamyl alcohol. $J$. Organomet. Chem. 2012, 717, 172-179.

[145] Pérez, Y.; Morante-Zarcero, S.; del Hierro, I.; Sierra, I.; Fajardo, M.; Otero, A. Asymmetric epoxidation of cinnamyl alcohol with optically active titanium complexes. Chirality 2006, 18(1), 44-48.

[146] Zhang, X.; Han, B.; Hua, Y.-N.; Huang, M.-Y.; Jiang, Y.-Y. Asymmetric epoxidation of cinnamyl alcohol 
catalyzed by silica-supported casein-Co complex. Polym. Adv. Technol. 2002, 13(3-4), 216-219.

[147] Ballesteros, R.; Fajardo, M.; Sierra, I.; del Hierro, I. Synthesis of titanium-triazine based MCM-41 hybrid materials as catalyst for the asymmetric epoxidation of cinammyl alcohol. J. Mol. Catal. A: Chem. 2009, 310(1), 83-92. 